4-2016

\title{
The Order to Pay Money in Medieval Continental Europe
}

\author{
Benjamin Geva \\ Osgoode Hall Law School of York University, bgeva@osgoode.yorku.ca
}

\section{Source Publication:}

David Fox and Wolfgang Ernst (eds.), Money in the Western Legal Tradition - Middle Ages to Bretton Woods (Oxford University Press)

Follow this and additional works at: https://digitalcommons.osgoode.yorku.ca/scholarly_works

Part of the Banking and Finance Law Commons

\section{Repository Citation}

Geva, Benjamin, "The Order to Pay Money in Medieval Continental Europe" (2016). Articles \& Book Chapters. 2614.

https://digitalcommons.osgoode.yorku.ca/scholarly_works/2614

This Book Chapter is brought to you for free and open access by the Faculty Scholarship at Osgoode Digital Commons. It has been accepted for inclusion in Articles \& Book Chapters by an authorized administrator of Osgoode Digital Commons. 


\section{IONEY}

NTHE

ESTERN

EGAL

ADITION

DOLE AGES BRETTON WOODS

ROX

$A N D$

ERNST

\section{MONEY IN THE} WESTERN LEGAL TRADITION

\author{
MIDDLE AGES \\ TO BRETTON WOODS
}

\author{
DDTATD BY \\ DAVTD IOX \\ WOLTGANG ERNST
}

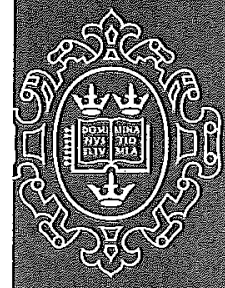

OXEORD

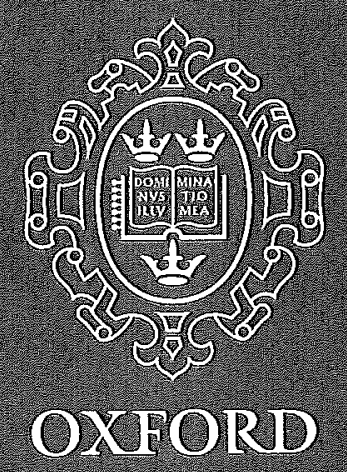




\title{
The Order to Pay Money in Medieval Continental Europe
}

\author{
Benjamin Geva
}

\author{
I. Introduction: Bankers, Banking, and Payments in Medieval \\ Continental Europe \\ II. Deposit and Transfer Banking in Medieval Continental Europe \\ III. Heralding the Bill of Exchange: The Medieval Continental Bill \\ of Payment \\ IV. The Bill of Payment: Legal Relationships \\ V. Conclusion: Medieval Continental Contribution Assessed

\section{Introduction: Bankers, Banking, and Payments in Medieval Continental Europe}

In the early centuries of the Middle Ages, the economy in Europe collapsed and trade was reduced to a trickle.* Monetary economy survived only in a rudimentary form; the last Roman banks disappeared in the course of the sixth and seventh centuries, and banking and non-cash monetary payment systems ceased to exist altogether. ${ }^{1}$

Banking services reappeared in Europe in the later part of the Middle Ages to satisfy the growing demands of trade. Bogaert points to Genoa as being the first city in which-moneychangers became bankers. ${ }^{2}$ Clearly, 'banking' in continental Europe, was reborn in Italy ${ }^{3}$ and

\footnotetext{
* This chapter is an edited version adapted from chapter 8 of B. Geva, The Payment Order of Antiquity and the Middle Ages-A Legal History (Oxford and Portland, Ore: Hart Publishing, 2011). See that book for acknowledgements and funding provision for this work.

${ }^{1}$ R. S. Lopez, 'The Dawn of Medieval Banking', in Centre for Medieval and Renaissance Studies University of California, Los Angeles (èd.), The Dawn of Modern Banking (1979) 1, at 3-5 (hereafter The Dawn of Modern Banking). For payments in kind assessed in monetary value and on occasion supplemented with low-value coins, which took place in the Carolingian Empire (eighth century CE), see, e.g., A. Murray, Reason and Society in the Middle Ages (1978, repr. 2002), at 31-5. For Roman banks, see B. Geva, The Payment Order of Antiquity and the Middle Ages-A Legal History (2011), ch 3, section 4.

${ }_{2}^{2}$ R. Bogaert, Les Origines antiques de la banque de dépôt (1966), at 167. Lopez, above $\mathrm{n} 1$, at 10, is more cautious; rather, he states, 'Genoa happens to preserve the earliest notarial minute books that have survived (from $1154 \mathrm{on})$... [which] are the first source that contains a fairly large number of documents showing bankers at work'.

${ }^{3}$ For developments in Medieval Spain, see A. P. Usher, The Early History of Deposit Banking in Mediterranean Europe (1943), vol. 1, at 237-504 (covering 1240-1723 in Catalonia); and further M. Riu, 'Banking and Society in Late Medieval and Early Modern Aragon', in The Dawn of Modern Banking, above n 1, 131. Particularly for extensive documentation, see also: A. E. Sayous, 'Les méthodes commerciales de Barcelone au XIVe siècle, surtout d'après des protocoles inédits de ses archives notariales', (1933) 18 Estudis universitaris Catalans 209, particularly at 217-23 (as well as at 231 and 233-4); and A. E. Sayous, 'Les méthodes commerciales de Barcelone au XVe siècle, d'après des documents inédits de ses archives' (1936) 15 (ser. 4) Revue historique de droit français et étranger 255, at 274-86 (hereafter Sayous, 'Méthodes commerciales XV'). For a broader earlier Christian- (namely West European-) Mediterranean perspective, see A. E. Sayous, 'L'histoire universelle du droit commercial de Levin Goldschmidt et les méthodes commerciales des pays chrétiens de la Méditerranée aux XIIe et XIIIe siècles', Pt. II (1931) Annales de droit commercial français, étranger et international 309, at 310-12, 317-20.
} 
'exported' elsewhere ${ }^{4}$ in the course of the twelfth and thirteenth centuries, as part of a commercial revolution that took place as of the eleventh century or so. The revolution occurred in the aftermath of the feudal anarchy of the manorial economy in the Middle Ages. ${ }^{5}$

Medieval 'banking' was not limited to financial intermediation. Broadly speaking, the medieval continental financier fell into one of three categories. ${ }^{6} \mathrm{~A}$ financier could be a pawnbroker, a moneychanger who accepted deposits, or a merchant banker dealing in exchange. ${ }^{7}$ The first category, pawnbrokers, consisted of lenders who lent out of their capital. ${ }^{8}$ They lent small amounts primarily for consumption, and played no role in the development of the payment system. The second category consisted of moneychangers who accepted deposits and whose practices were rooted in the manual exchange of coins. The third category consisted of exchange bankers whose practices emerged from the exchange of money in long distance trade. The principal activities of those belonging to the second and third categories were outside the usury prohibitions. ${ }^{9}$ Between the second and third categories, it was only the second category, that of deposit-transfer banking, that is associated with financial intermediation in the modern sense.

The second category is that of deposit bankers. These were moneychangers who began to obtain funds via deposits from the public. In accepting deposits they primarily borrowed funds with a view to lending or investing them. They further provided non-cash payment services, facilitating transfers on their books from one account to another, and were thus sometimes called transfer bankers. Members of the public were eager to deliver funds to them for safekeeping as long as these funds would remain available to depositors on demand.

The third category is that of merchant bankers. Large merchants, particularly those having branch networks or correspondents throughout Europe, became involved in the transmission of money from place to place. In the fourteenth and fifteenth centuries, they were predominantly Italian; in the sixteenth century, the centre of gravity shifted to Germany. ${ }^{10} \mathrm{~A}$ merchant banker received money in one place in one currency and had it paid in another place in another currency. Merchant bankers thus combined their foreign trade with exchange activity. The mechanism they used for the exchange gave rise to the modern bill of exchange. Since they dealt with currency exchange by means of the bill of exchange, they are also called exchange bankers. They settled their payment obligations in

\footnotetext{
${ }^{4}$ See, e.g., A. E. Sayous, 'Les Opérations des banquiers italiens en Italie et aux foires de Champagne pendant le XIIIe siècle' (1932) 170 Revie historique 1; and M. Prestwich, 'Italian Merchants in Late Thirteenth and Early Fourteenth Century England', in The Dawn of Modern Banking, above n 1, 77.

${ }^{5}$ For a detailed discussion on this general context, see R. De Roover, 'The Organization of Trade', in M. M. Postan, E. E. Rich, and E. Miller (eds), The Cambridge Economic History of Europe. Vol, 3: Economic Organization and Policies in the Middle Ages (1963, repr. 1979) 42.

${ }^{6}$ Lopez, above $\mathrm{n} 1$, at $6-7$.

7 R. De Roover, 'Banking and Credit in the Formation of Capitalism', in Fifth International Conference of Economic History Leningrad 1970 (1979), at 9. See, in detail, R. De Roover, Money, Banking and Credit in Mediaeval Bruges: Italian Merchant Bankers, Lombards and Moneychanger/Moneychangers: $A$ Study in the Origins of Banking (1948; repub. as The Emergence of International Business, 1200-1800 (1999) vol. 2).

${ }_{8}$ Members of this group could have been further divided into pawnshops, and retail banks, as was the case in Florence in the fifteenth century. The latter gave loans secured by jewellery, took time deposits but did not carry out book transfers, See, e.g., R. De Roover, The Medici Bank: Its Organization, Management, Operations and Decline (1948), at 1-2.

${ }^{9}$ R. De Roover, 'La structure des banques au moyen âge', in Troisième conférence internationale d'histoire économique, Munich, 1965 (1974), vol. 5, 159.

${ }^{10}$ For the transition, see, e.g. J. F. Bergier, "From the Fifteenth Century in Italy to the Sixteenth Century in Germany: A New Banking Concept?', in The Dawn of Modern Banking above $\mathrm{n} 1,105$.
} 
fairs by a mechanism that heralded organized interbank clearing and settlement systems in a multilateral setting. ${ }^{11}$

The following discussion outlines the evolution of the principal institutions and mechanisms associated with the second and third categories of medieval financiers. Section II deals with deposit and transfer banking. Sections III and IV deal with the bill of payment: Section III covers its evolution and Section IV discusses the legal relations under it. Section III also covers the interbank settlement mechanism for bills of payment that is the forerunner of organized interbank clearing in a multilateral setting. Section V provides a summary of the medieval contribution to the evolution of the modern payment system.

\section{Deposit and Transfer Banking in Medieval Continental Europe}

The term designating a banker, bancherius, is derived from banca, meaning 'table', which refers to the table at which the moneychanger did business. Genoese notarial records from the period between 1155 and 1216 clearly identify moneychangers as the first bankers. Moneychangers made their first appearance as such late in the twelfth century. ${ }^{12}$ The same records also identify wealthy merchants as conducting isolated banking transactions as incidental activities earlier in that same century. It is, however, the moneychanger that came to conduct different types of banking transactions as a principal business activity. At the same time, the banker did not have a monopoly on such transactions and services, which continued to be provided by other businesses despite the transformation of the moneychanger into a banker. ${ }^{13}$

As far as these Genoese notarial records indicate, 'banking' ought to be understood as consisting of intercity exchange, the extension of credit, and deposit-taking. Most of the exchanges took place between Genoa and the fairs and were carried out by wealthy merchants and not moneychangers. Credit operations were in the form of business loans. Deposit-taking originally took the form of 'a strong-box sort of contract, which obliged the custodian to return the identical objects entrusted to his care'. ${ }^{14}$ However, with the advent of the commercial revolution, depositors became more and more interested in having their funds produce a profit; at the same time, the bankers came to view the deposits they received as capital to be invested by them for their own profit. Gradually, business arrangements began to develop between depositor and depositary-banker. At the start, the banker would invest deposit funds for the mutual benefit of both himself and the depositor under a profit-sharing agreement. Subsequently, bankers commenced to give depositors a fixed rate of interest. ${ }^{15}$ It was thus primarily the moneychangers who began to take deposits and extend credit.

\footnotetext{
11 For 'the great international merchant-bankers', inventors of the bills of exchange as a separate category from 'the moneychangers, who dealt in actual exchange of coins and the trade in bullion and precious stones', see, e.g." I. Origo, The Merchant of Prato (1957; repr. 1986), at 147. But see Holdsworth, who (I submit, erroneously) attributes the invention, use, and development of the bill of exchange to moneychangers, or in his language, to 'the exchangers, whose business it was to give coins of one state in exchange for the equivalent value of coins of another state': W. Holdsworth, A History of English Law (2nd edn, 1937; repr. 1966) vol. 8, at 128. 'Money change' and 'exchange' are also used interchangeably by C. Verlinden, 'Markets and Fairs', in Postan et al. (eds), above n 5, 119, at $136-7$.

${ }_{12}$ And yet parallel developments took place around the same time elsewhere in Italy. See T. W. Blomquist, "The Dawn of Banking in an Italian Commune: Thirteenth Century in Lucca', in The Dawn of Modern Banking, above n 1 , at 53 .

${ }_{13}$ See in detail M. W. Hall, 'Early Bankers in the Genoese Notarial Records', (1935) 6 Economic History Review 73.

14 Ibid., at 76-7.

15 The rate of interest was agreed in advance, and yet, in order not to be in flagrant violation of usury laws, the agreement could have nominally called for a rate of return in the banker's profits, determined at the banker's 'discretion'. See R. De Roover, 'New Interpretations of the History of Banking', in J. Kirshner (ed.), Business,
} 
Genoese notarial registers do not record non-cash payment activities. ${ }^{16}$ Other records do. An important source of information as to the existence of book transfers is a set of testimonies relating to a lawsuit in Genoa in 1200 , which was recorded by a notary. Witness statements make the following germane points regarding the operations of Genoese bankers. ${ }^{17}$ First, merchants had bank accounts and used them to make payments by means of a book transfer; second, credit was extended to depositors by means of overdrafts; and third, interbank arrangements existed for the facilitation of non-cash payments between accounts kept with different bankers.

To make book transfers, customers were required to appear in person at the bank. Apparently, then, payment orders were oral. The procedure for an interbank payment and settlement is unclear, ${ }^{18}$ and procedures as well as perhaps bookkeeping methods may not have been completely reliable. ${ }^{19}$

In the medieval era, deposit banking is said to be the outgrowth of manual exchange. ${ }^{20}$ As originally in ancient Greece, ${ }^{21}$ it was the moneychangers who began to take deposits from the public. By 1350, in becoming bankers, ${ }^{22}$ moneychangers developed a system of local payments by book transfers, with a view to eliminating ' $t$ ] he great inconvenience of making all payments in specie, especially the waste of time involved in counting coin.' ${ }^{23}$ As in twelfth-century Genoa, the system that developed was strictly local; no facility for intercity book transfers is known to have existed throughout the Middle Ages.

Indeed, this pattern is evidenced by Venetian banking experience. Between the late thirteenth and early fourteenth centuries, the moneychangers of Venice, the campsores, became bankers. ${ }^{24}$ They accepted deposits, lent deposited money, and provided payment services from and to current accounts kept with them. ${ }^{25}$ According to a study on Venice banks in the fourteenth and fifteenth centuries:

The convenience offered by medieval banks was conceivably as important to contemporary businessmen as are chequing accounts today. The potential depositor was likely to acquire many various currencies, foreign and local, legal and non-legal tender, good and bad. These he would bring to the banker, who would weigh and evaluate them and accept them at their intrinsic or market value calculated in money of account. The money of account, in turn, was the expression of the legal tender standard maintained by the government mint. 'The money changer/banker, perhaps after deducting an exchange fee or commission, gave the depositor credit on his books by opening an account in his name. The demand deposit is a liability on the banker's balance sheet and is the client's claim on the specie he deposited. His transferable asset now merely 'consists of figures in bank ledgers and is money only because of confidence in the ability of the banks to honour their liabilities when called upon to do so.' It becomes a kind of fiduciary

Banking, and Economic Thought in Late Medieval and Early Modern Burope: Selected Studies of Raymond de Roover (1974; 1976), at 201-2 and R. A. Goldthwaite, 'The Medicl Bank and the World of Florentine Capitalism', (1987) 114 Past and Present 3, at 14. See also De Roover, above n 8, at 5, nominally 3 and, in general, 52-9.

${ }^{16}$ Hall, above $\mathrm{n} 13$, does not even mention them.

17 R. L. Reynolds, 'A Business Affair in Genoa in the Year 1200: Banking, Book-keeping, a Broker(?) and a Lawsuit', in Studi di storia e diritto in onore di Entico Besta (1938), vol. 2, 165, at 171-2.

18 De Roover, above n 15, at 202.

19 Reynolds, above n 17, at 171.

20 The view that attributes an important role in the early era of banking to the lending function, expressed by Sayous, above $\mathrm{n} 4$, at 2 and 6 , is now disfavoured. See, e.g., Hall, above $\mathrm{n}$ 13, at 76 and De Roover, above $\mathrm{n}$ 15, at 202.

21 See Geva, above n 1, ch 3, section 3, at 118-24. $\quad 22$ De Roover, above $\mathrm{n} 15$, at 213.

${ }^{23}$ See R. De Roover, 'What is Dry Exchange?', in Kirshner (ed,), above n 15, 183, at 184.

${ }^{24}$ Holdsworth, above in 11 , at 178.

${ }^{25}$ See, in detail, R. C. Mueller, 'The Role of Bank Money in Venice, 1300-1500', in Fondazione Giorgio Cini et al. (eds), Studi veneziani (NS) (1979), vol. 3, 47. The ensuing discussion is based on this paper. 
money, a claim for which the banker has substituted his 'promise to pay' for that of the depositor in the making of payments. ${ }^{26}$

Customers held current accounts, in which deposits were made, to be used for book transfers. Parties to a book transfer had to appear in person before the bankers; that is, only oral payment orders were accepted. Written orders, as distinguished from letters authorizing agents to act on behalf of parties, did not exist. The inscription by a banker of a debit and credit in a current account was authoritative as a notarial instrument, and hence reliable. Bankers held accounts with each other. This allowed for interbank transfers, albeit under a mechanism which is not clear to researchers today. ${ }^{27}$

Accounts among major banks may have been settled only on irregular intervals. In fact, the holding of correspondent accounts by banks with each other was often abused. Such was the case when a customer wishing to withdraw cash was sent by his banker to a correspondent (holding an account for the customer's banker)-who may have sent the customer to another correspondent (holding an account for the correspondent of the customer's banker)-and so on.

Banks kept with them only a fractional reserve, namely a limited amount of coined money, ready to satisfy an anticipated demand for cash withdrawal; they lent or invested most money received on deposit. Availability of payment by book transfers, recognized by early-fourteenth-century legislation in Venice, allowed banks to reduce cash holdings even further and increase their investments and credit extensions.

Loans were made by banks in coin, by way of an overdraft allowed to be incurred on a current account, and in the form of a credit entry to a current account. This required tight regulation dealing with a variety of subjects, such as banks' obligations to pay in cash on demand, the discouragement of banks to send customers seeking cash from one bank to another, and above all, the licensing of banks, a procedure which included a requirement to post surety with a state magistracy before being licensed. While there were no circulating banknotes, the system as a whole expanded the monetary base, so that money actually consisted of coins in the hands of the public plus deposits kept with banks. Such deposits served as 'bank money' and were very popular in making a variety of commercial, rental, and government payments.

This local banking system was typical for continental Europe throughout the fourteenth and fifteenth centuries. According to Huvelin, the banker's promise to the payee could be explained under Roman law as receptum argentarii. ${ }^{28}$ The receptum was a banker's promise, acting under the instruction of his client and for the client's accommodation, to perform on a fixed date towards a third party. ${ }^{29}$ Huvelin was cognizant that, by the time of Justinian's reform projects in the sixth century, the receptum argentarii had gone into

\footnotetext{
${ }^{26}$ Mueller, above n 25, at 48 .

${ }^{27}$ Possibly, the procedure for an interbank transfer also required each banker to appear before the other. One may speculate that, first, the two parties appeared together with the payee's banker before the payer's banker, and, subsequently, the two parties appeared together with the payer's banker before the payee's banker. Alternatively, the presence of the bankers was dispensed with, as they relied on each other, and anyway would settle only periodically, so that it was only the parties themselves that had to attend at each banker. Either way, it looks as if the procedure required two 'attendances' at a banker's place as opposed to one only in an in-house transfer on the books of the same bank. Note, however, that contrary to Mueller, above in 25, at 74-6, M. Manning, E. Nier, and J. Schanz (eds), The Economics of Large-value Payments and Settlement: Theory and Policy Issues for Central Banks (2009), at 24 find 'no conclusive evidence' for interbank transfers in Medieval Venice.

${ }^{28}$ P. Huvelin, 'Travaux récents sur l'histoire de la lettre de change', (1901) 15(1) Annales de droit francais, étranger et international 1 , at 20-1 and fn. 1 .

29 See Geva, above $n 1$, ch 5, section 5 , at 210-14.
} 
disuse, ${ }^{30}$ but claimed that this was confined to the Eastern Roman Empire and did not reflect the reality in Italy, ${ }^{31}$

One advantage of this explanation is that under the receptum argentarii, the banker's undertaking is independent, namely entirely autonomous, free of defences that may have been available to the client against the third party. At the same time, the banker's undertaking to the third party under receptum argentarii does not affect the client's own original obligation to the third party, so that it was not equivalent to be a full discharge of that obligation. ${ }^{32}$ This explanation is, however, contrary to the prevailing understanding of the medieval bank book transfer mechanism, which was that it provided a complete discharge of the payer-client's obligation. Hence, the receptum argentarii explanation of payment and discharge may be unsatisfactory.

An alternative analysis is provided by De Roover, who speaks of the method of payment by book transfer as an 'assignment in bank', which '[a]ccording to the medieval jurists... discharged the debtor from any other obligation. ${ }^{33}$ Relying particularly on the fourteenth-century Italian jurist, Bartolo Da Sassiferrato, he refers to the book transfer as an 'assignation', ${ }^{34}$ requiring the consent of the debtor, banker, and creditor. When that transaction occurs in a bank, the debtor is irrevocably discharged, so that the transfer is equal to payment in current coins. This is so 'on condition that the banker or money changer promises the creditor to hold the sum transferred at the creditor's disposition'. This rule effectively treats the book entry on the banker's books as an absolute discharge of the original debt, upon which the creditor forfeits his recourse against the original debtor. The rule is said, however, to apply only to a bank transfer. In other cases of an 'assignation', namely one involving a third party other than a public moneychanger, the creditor keeps his right of recourse against the debtor to be used where the non-bank third party declines to honour his undertaking. ${ }^{35}$

De Roover's reasoning appears to be premised on cessio, namely, the transfer to the payee/creditor of the debt owed by the banker to the payer/debtor. However, cessio does not explain the autonomy of the banker's obligation, that is, its enforceability by the payeecreditor against the banker free of defences that may have been available to the banker

${ }^{30}$ A point highlighted in Justinian's Code, BK IV, Title XVIII, para, 2, in Corps de droit civil romain, vol. 9 (trans. P. A. Tissot, 1807; repr. 1979), at 39.

31 Huvelin, above $\mathrm{n} 28$, at $20, \mathrm{fn} 1$.

32 As discussed in Geva, above $n 1$, ch 5 section 5 , at 210-14.

${ }^{33}$ De Roover, above $\mathrm{n} 15$, at 215 and 216 (respectively).

34 For the 'assignation' as the assignment or cession with recourse, see, e.g., J. Duponchel, De la cession d'actions en droit romain: Du titre dordre et des conséquences qui s'y rattachent en droit français (1870), at 10. Terminology on the point is, however, quite confusing. For example, in Scotland, 'assignation' is used to denote 'assignment'. See, e.g., S. Styles and N. R. Whitty (eds), Glossary of Scottish and European Union Legal Terms and Latin Phrases (2nd edn, 2003), at 17, defining 'assignation' as 'the act of transferring rights in in British Linen Co. $y$ Hay er Robertson and Brown (1885) 22 SLR 542 (First Division); and J. Bouvier, A Law Dictionary: odopted to the constitution and laws of the United States of America, and of the several states of the

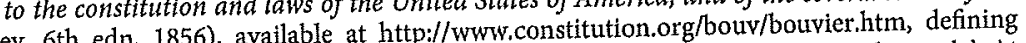
American Union (rev. 6th edn, 1856), avallable at http://www.const which intimation must be made'. At 'assignation' in Scots law as ' $[t]$ he ceding or yielding a thing to another of which intimation must be made , At the same time, the Swiss Code of Obligations distinguishes (in French) between assignation and "cession (Arts 466 and 164, respectively), the former being an order or authorization to pay and the latter being an assignment of a right.

${ }^{35}$ R. De Roover, L'Evolution de la Lettre de Change XIVe-XVIIIe siècles (Paris: Librairie Armand Colin, 1953), (13 the three pages he summarizes the views of Bartolo Da Sassofferato (1314-57), Baldo Degli Ubaldi (1327-1400), and Giasone Del Maino (1435-1519). De Roover acknowledges (ibid,, at 208) Bartolo's text to be 'obscure' but claims to follow its usual interpretation including by the two other jurists. Ibid., at 85-7: De Roover refers to the distinction between a book transfer with a banker and that with another debtor, a point to be revisited in Section V in relation to the origins of 'endorsement'. 
against the payer-debtor. ${ }^{36}$ In fact, De Roover's explanation is not based on cessio, as he specifically mentions a requirement as to the consent of all three, namely the payer, banker, and payee, and not only that of the payer and the payee, as would have been the case under cessio. True, a banker is likely to agree to the transfer of a credit balance from the account of one customer to that of another, and may be in breach of contract if he declines to act on the transfer instructions; hence the banker's consent is likely to be routinely given. At the same time, his consent and affirmative response in the form of posting on his books the entries reflecting the book transfer is an essential component of the payment transaction; this precludes the book transfer from being a mere cessio from the payer-debtor to the payee-creditor. Rather, inasmuch as the payer's discharge is premised on the banker's autonomous obligation towards the payee, other than the absence of required formalities, the operation of the bank book transfer is reminiscent of a perfect execution of a delegation order by means of novation by stipulation under Roman law. ${ }^{37}$

The medieval banking book transfer thus requires the presence and consent of all three parties, namely, debtor-payer, creditor-payee, and paymaster-banker. Strictly speaking, then, in not being satisfied with a bilateral agreement, it could be classified neither as a delegation, ${ }^{38}$ requiring the creditor-paymaster's agreement, nor as an assignment cessio, requiring only the debtor-creditor agreement. ${ }^{39}$ At least in a superficial way, it is reminiscent of the Talmudic 'presence-of-all-three' declaration..$^{40}$

For its part, the presence-of-all-three requirement, and hence, the lack of reliance on a written instruction, had a strong tendency to eliminate fraud. The requirement was not a source of inconvenience, because usually all three parties were situated in the same vicinity and the banker tended to keep his books available on his desk. ${ }^{41}$ However, on occasion, the debtor was perhaps ill and thus prevented from coming to the banker. It was on such rare occasions that written payment orders started to be used. Gradually, however, by the fourteenth and fifteenth centuries, written payment orders spread and became common, first in Italy, outside Venice, and particularly in Tuscany, including Florence, and then elsewhere outside Italy. ${ }^{42}$ Initially, '[w] ritten instruments could be used ... only as supplementary memoranda or as instruments appointing an agent'. ${ }^{43}$ Ultimately, their presentment to the banker by one party dispensed with the presence of the other party.

It may be that some of these payment orders were, in effect, cheques, each issued by the payer/debtor to the payee/creditor, instructing the banker to pay to the creditor, as well as authorizing the creditor to collect from the banker. ${ }^{44} \mathrm{It}$ is in this process that a medieval cheque mechanism was born. Medieval cheques were not negotiable, and were usually even non-transferable. ${ }^{45}$ It may be that they were not widely used other than at specific

\footnotetext{
${ }^{36}$ The general rule is that the transferee under cessio takes the debt subject to defences available to the obligor against the transferor. See Geva, above n 1, ch 5, section 9, at 233-41.

37 As discussed in ibid., ch 5 , section 6 , at 214-23.

${ }^{38}$ For the perfect execution of the delegation by means of novation by stipulation, see ibid.

39 For cessio in Roman law, see ibid, ch 5, section 9, at 233-41.

${ }^{40}$ Discussed at length in ibid, ch 7 , section 3 , at 330-42.

41 A point highlighted by Usher, above $\mathrm{n} 3$, at 90 , where he speaks of 'the custom of transacting all important business in person if possible' as facilitated by ' $[\mathrm{t}] \mathrm{he}$ compactness of medieval and early modern towns and the concentration of the commercial community'.

42 For Barcelona, see, e.g., ibid., at 283-8. $\quad 43$ Tbid., at 283.

44 For this nature of the cheque, see Geva, above $\mathrm{n} 1, \mathrm{ch} 4$ (possible Talmudic origins) as well as ch 3 , section 5 , at 140-55 (Greco-Roman Egypt).

${ }^{45}$ However, notwithstanding sources in the ensuing note, see the in-depth discussion (in Italian) of F. Melis, Note di storia della Banca pisana nel trecento (1955) on an extensive cheque collection from the second half of the fourteenth century in Tuscany. Melis identifies cheques transferable by the instruction of the payee placed on the back (recto) of the cheque (ibid, at 112, by reference to ibid,, at $98 \mathrm{fn} 244$ ). The example given is of a situation in which the transferee was identified in the original cheque, that is, the payee was authorized to transfer the cheque
} 
times and places. ${ }^{46}$ They initiated either a payment in cash or a book transfer. Either way the cheque accomplished 'the transfer of the creditor's right to a third party ${ }^{347}$ and thus did not generate a legal perspective of its own.

Major innovations took place in Amsterdam, presumably in the transition from the sixteenth to the seventeenth century. Thus, moneychangers, who were 'transformed' into 'cashiers' (or kaissiers in Dutch), facilitated payments initiated by 'written ... assignaties'. These instruments, which embodied depositors' payment orders given to their 'cashiers', 'acted as checks' that '[1]ike bills of exchange... were endorsable and thus might pass, as means of payment, from hand to hand'. ${ }^{48}$ In addition, the receipts that 'cashiers' issued to their depositors 'could take the form of promises to (re)pay the sum deposited'. As such, these instruments served as goldsmith notes, and 'equally became negotiable by endorsement'. Gradually, such promises became payable to bearer, and 'effectively raised the money supply' ${ }^{49}$ 'This reads as a forerunner of the English goldsmith system that heralded modern banking. However, in Amsterdam, a parallel development was arrested with the establishment of the Bank of Amsterdam (the Wisselbank) in 1609, whose operations superseded to a large extent, those of the moneychangers. ${ }^{50}$

Indeed, throughout the Continent, during the fifteenth century, private deposit banks declined. Repeated bank failures undermined the confidence of merchants and further triggered hostility by public authorities. ${ }^{51}$ Together with a chronic shortage of good coins, increased risk in keeping money with a banker led to a devaluation of 'bank money' compared to that of 'coined money'. ${ }^{52}$

Prohibitions against private deposit and transfer banking were further prompted by the perception of authorities throughout Europe that 'money-changers acting as deposit bankers' threatened 'the integrity of the ducal mints and coins'. This threat was premised on the allegation that moneychangers were involved in 'circulating debased and counterfeit

to a specified transferee, from which I gather that no further transfer could have been made. 'This is, of course, a far cry from free circulation. I relied on an informal partial translation of Melis.

${ }^{46} \mathrm{See}$, in general, De Roover, above $\mathrm{n} 15$, at 216-17, as well as Usher, above $\mathrm{n} 3$, at $90-4$. For an extensive discussion, see M. Spallanzani, 'A Note on Florentine Banking in the Renaissance: Orders of Payment and Checks', (1978) 7(1) Journal of European Economic History 145. The author points out (e.g., ibid., at 146) the difficulty in identifying with certainty those payment orders which are cheques. Furthermore, his definition of 'check' (ibid, at 148), as 'an order of payment issued on a bank... by someone who has funds available', is too broad and in effect does not distinguish between cheques and other payment orders. At the same time, my overall impression from the article is that he speaks of a 'check' in the correct sense.

47 Usher, above in 3, at 91, referring in the quoted language to the depositor-drawer as 'creditor' (of the bank) and to his own (the 'creditor'-depositor-drawer's) creditor, namely to the payee, as the 'third party'.

${ }_{48}$ The origins of the endorsement of the bill of exchange is discussed in Geva, above $\mathrm{n} \mathrm{1,} \mathrm{ch} \mathrm{8,} \mathrm{section} \mathrm{5,} \mathrm{at}$ 401-18. For such developments during this period, see also D. De Ruysscher, 'Innovating Financial Law in Early Modern Europe: Transfers of Commercial Paper and Recourse Liability in Legislation and Ius Commune (Sixteenth to Eighteenth Centuries)' (2011) 19 European Review of Private Law 505.

${ }_{49}$ All quotes in this paragraph are from $P$. Dehing and $M$. 'T Hart, 'Linking the Fortunes: Currency and Banking, 1550-1800', in M. 'T Hart, J. Jonker, and J. L. Van Zanden (eds), A Financial History of the Netherlands (1997), at 37, 43. See also P. Spufford, 'Access to Credit and Capital in the Commercial Centres of Europe', in K. Davids and J. Lucassen (eds), A Miracle Mirrored: The Dutch Republic in European Perspective (1995) 303, at 306.

50 Dehing and 'T Hart, above $n$ 49, at 43-4. Note that with the establishment of the Bank of Amsterdam in 1609 'the municipal authorities of Amsterdam temporarily prohibited all moneychangers and cashiers and their paper money...'. The ban was lifted in 1621 'and the remaining moneychangers and cashiers became licensed officials'. However, in this new capacity, cashiers were required to hold accounts with the Bank of Amsterdam and were prohibited from keeping money in specie for longer than 24 hours. The English goldsmith system is discussed in Geva, above n 1, ch 10, section 2, at 469-84.

${ }^{51}$ De Roover, above n 15, at 219.

52 F. C. Lane, Venice: A Maritime Republic (1973), at 328-9; for the same phenomenon in Venice at a later period, see ibid., at 402. See also F. C. Lane, "Venetian Bankers, 1496-1533: A Study in the Early Stages of Deposit Banking', (1937) 45 Journal of Political Economy 187, at 200-1. 
foreign coins and buying coin and bullion for export' in violation of restrictions on coinage and trade in precious metal..$^{53}$ Ultimately, in a process that 'did not gain momentum until the last quarter of the sixteenth century', public banks gradually replaced private banks in commercial centres. ${ }^{54}$ Heralding this development, Venice gave rise to a 'distinctive style' of banking, referred to as giro banking, under which the primary purpose of banks was the making of payments on behalf of customers rather than making loans. ${ }^{55}$

Continental public banks that followed and expanded on this model were exchange banks, at which bills of exchange, which are discussed in the following section, were required to be payable, so as to compel merchants to open accounts with them..$^{56}$ Otherwise, these banks were predominantly deposit and transfer banks. Some allowed the use of cheques (or 'assignations') ${ }^{57}$ others insisted on oral orders in the presence of all parties. All were originally precluded, and later strictly restricted, from lending or making investments. At most, they were allowed to make advances to their own governments and to certain select institutions; the extension of credit to others, by way of overdraft or otherwise, was however strictly forbidden. ${ }^{58}$ They did not provide financial intermediation and were not 'banks' in the full modern sense of the word. ${ }^{59}$

Public banks provided an efficient mechanism for local payments by means of book transfers. At times, the value of the 'bank money' deposited with public banks was higher than the same amount in coined money. ${ }^{60}$ This was so because it represented money exactly according to the standard of the mint'. Moreover, such 'bank money' was secure from fire, robbery, and accidents; it was also easily transferable; ${ }^{61}$ it reduced risk and was part of a system that provided adequate supplies of good coined money to satisfy actual demand for it. ${ }^{62}$ The Bank of Amsterdam, 'established in 1609 under the guarantee of the city', ${ }^{63}$ was a leader among the public banks. ${ }^{64}$

53 J. H. Munro, 'The:Medieval Origins of the Financial Revolution: Usury, Rentes, and Negotiability', (2003) 25 International History Review 505, at 548, speaking of fifteenth-century 'economically advanced Low Countries'.

${ }^{54}$ De Roover, above n 15, at 223. For the public bank in Venice as a successor of the private bank system, which failed primarily due to excessive lending by means of simple book entries, see C. F. Dunbar, 'The Bank of Venice', (1892) 6 Quarterly Journal of Economics 308; and G. Luzzatto, 'Les banques publiques de Venice (siècles XVIXVIII)', in J. G. Van Dillen (ed.), History of the Principal Public Banks (1st edn, 1934; repr. 1964), at 40. See further Chapter 17 in this volume.

$55^{\circ}$ Lane, Venice, above n 52, at 147 . See also Lane, 'Venetian Bankers', above n 52, at 187 , specifically rejecting earlier such institutions and stating that 'Giro banks did not come into existence until the late sixteenth century, at Venice in 1584'.

${ }^{56}$ For example, for the Bank of Amsterdam (founded at the beginning of the seventeenth century), see J. G. Van Dillen, 'The Bank of Amsterdam', in Van Dillen (ed.), above n 54, 79, at 84.

${ }^{57}$ See, e.g., for the Bank of Amsterdam, ibid., at 86 where it is further stated that ' $[\mathrm{t}]$ he assignations should be handed by the customer personally or by his proxy'.

${ }^{58}$ De Roover, above n 15, at 228. This is consistent with the description given by G. Malynes, Consuetudo, vel Lex Mercatoria or The Ancient Law Merchant (1622), at 133 as to the use of 'money... remaining in the Bankers hands'.

59 For these banks, see Van Dillen (ed,), above $n 54$.

${ }^{60}$ Van Dillen, above $n$ 56, at 88 , specifically speaks of 'banco-florin' or 'banco-money' as distinguished from the inferior metallic 'current florin' or 'current money'.

${ }^{61}$ Adam Smith, The Wealth of Nations (1776; ed. E. Cannan 1976), vol. 1, at 504 in relation to the Bank of Amsterdam; cited in agreement (as 'Adam Smith Bk iv chap iii') by Holdsworth, above $n$ 11, at 180.

62 This is in contrast to the reverse fifteenth-century process devaluating bank money set out at De Roover, above n 15, at 219; Lane, Venice, above n 52; Lane, 'Venetian Bankers', aboven 52, and text accompanying nn 51-2 above.

${ }^{63}$ Smith, above $\mathrm{n} 61$, at 504 . See further Chapter 17 of this volume.

${ }^{64}$ See, e.g., Van Dillen, above n 56; Smith, above n 61, at 503-13; Dehing and 'T Hart, above $n$ 49, at 45-51; and S. Quinn and W. Roberds, 'The Big Problem of Large Bills: The Bank of Amsterdam and the Origins of Central Banking' (22 January 2007). (For an earlier version of this article, see Federal Reserve Bank of Atlanta, Working Papers Series 2005-6 (August 2005), albeit the latter contains lots of econometrics, which is inaccessible to a nonspecialist such as myself). For money and banking in Amsterdam, see also J. De Vries and A. Van Der Woulde, The First Modern Economy: Success, Failure, and Perseverance of the Dutch Economy, 1500-1815 (1997), at 81-91, $129-34$. 


\section{Heralding the Bill of Exchange: The Medieval Continental Bill of Payment}

International medieval banking is primarily associated with the exchange activity of merchant bankers. This activity gave rise to the modern bill of exchange.

Under modern legislation, ${ }^{65}$ the bill of exchange (or draft) is an unconditional written signed order, addressed by one person to another, requiring the addressee to pay a sum certain in money. It may be payable to the order of a designated payee or (though not everywhere) to the bearer, on demand or at a fixed or determinable future time. ${ }^{66}$ It may be transferred from one person to another by 'negotiation', consisting of either a mere delivery in the case of a bill payable to the bearer, or of delivery plus the transferor's signed 'endorsement ${ }^{67}$ in the case of a bill payable to the order. ${ }^{68}$ Under certain conditions, ${ }^{69}$ it may be enforceable by its holder for its entire sum, free of third party's adverse claims, as well as of any party's contract defences. ${ }^{70}$ 'The instrument is referred to as 'negotiable' due to its transferability by 'negotiation' and the power of 'negotiation' to 'improve' on the transferee's title. ${ }^{71}$ Throughout its history it has served as a credit and payment mechanism.

De Roover identified two stages in the history of the bill of exchange from its inception to the end of the sixteenth century. The first lasted approximately from 1275 to 1350 . At that stage, liability on the bill of exchange required a notarial confirmation of the signature. ${ }^{72}$ This requirement disappeared in the second stage, which lasted until the end of the sixteenth century. With the disappearance of the notarial requirement, the instrument

65 Particularly the English Bills of Exchange Act 1882 (c 61) (hereafter BEA), on which legislation throughout the world is modelled in common law jurisdictions and others that have been under British influence; Convention Providing a Uniform Law for Bills of Exchange and Promissory Notes, 7 June 1930, 143 LNTS 257, Annex I, on which legislation throughout the world is modelled in civil law countries including those in Continental Europe (hereafter Geneva Bills Convention); the Uniform Commercial Code UCC, Art. 3 (1990, as amended 2002) (hereafter UCC); and United Nations Convention on International Bills of Exchange and International Promissory Notes (UN Doc. A/RES/43/165), (1988) 42 Yearbook of the United Nations 834 (hereafter UNCITRAL Bills Convention).

66 Relevant provisions, in each case in conjunction with immediately ensuing ones, are BEA, above n $65, s$. 3(1); Geneva Bills Convention, above n 65, Art. 1 ; UCC, above n 65, § 3-104; UNCITRAL Bills Convention, above n 65 , Art. 3(1) (the latter two do not cover a bill stated to be payable to bearer).

67 According to I. M. Holden, The History of Negotiable Instruments in English Law (1955, repr. 1993), at 44, fn 6, " $[t]$ he spelling "endorse", is more common than "indorse" in commercial practice... At the same time', he goes on to say, "[t] he Bills of Exchange Act, 1882, adopted the spelling "indorse"'. I should add that on that point UCC, above n 65, Art. 3 follows suit and uses 'indorse'. In contrast, the Canadian spelling, reflected in the Bills of Exchange Act, RSC 1985, c B-4, and adopted in this text, is 'endorse".

68 BEA, above n 65, s. 31; Geneva Bills Convention, above n 65, Art. 11; UCC, above n 65, \$3-201; UNCITRAL Bills Convention, above n 65, Art. 13. The term 'negotiation' appears only in the BEA and UCC Art. 3. An endorsement which does not designate the transferee is an endorsement in blank, which effectively 'converts' the bill into one payable to the bearer. This is true even where instruments originally issued payable to the bearer are not recognized. For the 'conversion' by blank endorsement of the bill payable to order see, e.g., BEA, s. 34(1); Geneva Bills Convention, above n 65, Arts. $2-13$; UCC, above n 65, $\$ 3-205$; UNCITRAL Bills Convention, above n 65, Arts. 13-16.

69 Fundamentally, these conditions refer to the taking of the instrument by the holder in good faith, without knowledge, and for value. See, e.g., BEA, above n 65, s. 29(1); Geneva Bills Convention, above n 65, Arts. 16-17; UCC, above n 65, § 3-302; UNCITRAL Bills Convention, above n 65, Art. 29.

${ }^{70}$ See, e.g., BEA, above n 65, s. 38(2); Geneva Bills Convention, above n 65, Arts. 16-17; UCC, above n 65 , $\S \S 3-305$ and 3-306; UNCITRAL Bills Convention, above n 65, Art. 30.

71 For an extensive discussion on the negotiability concept and the definition of a negotiable instrument, see D. V. Cowen and L. Gering, Cowen on the Law of Negotiable Instruments in South Africa. Volume 1: General Principles (5th edn, 1985), at 1-70.

72 For the early bill of payment as a notarial instrument, see, e.g., A. E. Sayous, 'L'origine de la lettre de change" (1933) 12 (ser. 4) Revue historique de droit français et étranger 66; A. E. Sayous, 'Note sur l'origine de la lettre de change et les débuts de son emploi à Barcelone (XIVe siècle)', (1934) 13 (ser. 4) Revue historique de droit français et étranger 315; and Sayous, 'Méthodes commerciales XV', above n 3, at 274-86. 
nevertheless retained some formal language, ${ }^{73}$ and yet had become an ordinary informal letter, ${ }^{74}$ written by non-lawyers and without the benefit of legal advice, as part of ordinary commercial correspondence between merchants. ${ }^{75}$ During these two stages, the instrument was not negotiable and served as an evidentiary document required for the execution of the exchange contract. ${ }^{76}$ During that period, discussed in this section, the instrument is referred to as a bill or letter of payment. ${ }^{77}$ This section analyses the effect of bills of payment, and the principal features of their use as a mechanism for the settlement of obligations in the Middle Ages.

The bill or letter of payment existed, and probably originated, as a mechanism for the execution of the medieval contract of cambium. ${ }^{78}$ The adoption of that use is not contested by those claiming an earlier ancestry of the bill of payment, ${ }^{79}$ whose views are in any event strongly contested. ${ }^{80}$ The cambium contract has three meanings, all denoting certain exchanges. ${ }^{81}$ First, in its broadest Romanist jurisprudential sense, it is a contract by which a species of one genus is exchanged for another species of the same genus. Second, in a narrower sense, it is a contract for the exchange of money for money. Third, in the narrowest sense, it is a contract for the exchange of money of one currency with money of another currency and the transportation of the money received to another place. However, transportation need not be physical. Rather, as a mechanism for the execution of the medieval contract of cambium in that narrowest sense, the letter of payment 'made it possible to transfer purchasing power without the shipment of actual coins', ${ }^{82}$

In its broadest sense, as a contract for the exchange between two species of the same genus, cambium is a subcategory of barter, or permutatio. The latter denotes an exchange in general, which otherwise is concerned with the exchange of a species of one genus with a species of another genus. ${ }^{83}$

${ }^{73}$ M. T. Boyer-Xambeu, G. Deleplace, and L. Gillard, Private Money os Public Currencies; The Sixteenth Century Challenge, trans. A. Azodi (1994), at 30.

${ }_{74}$ Origo, above n 11, at 147.

${ }^{75}$ Sayous, 'Méthodes commerciales XV', above $n 3$, at 276. Notarial requirement reappeared however in connection with a proof of dishonour (ibid, at 285).

${ }_{76}$ De Roover, above n 35 , at $18-19$. A third stage lasted nearly until the end of the eighteenth century. During that stage, the instrument acquired its negotiability features; particularly, it became transferable either by delivery alone, or by delivery and endorsement, and gradually lost its connection to the exchange contract. De Rover enumerates two subsequent periods, one of expansion, in the nineteenth century during which the bill of exchange became discountable, followed by a subsequent contraction in terms of actual use.

77 Huvelin, above $\mathrm{n} 28$, at 5 . Cf. De Roover, above $\mathrm{n} 35$, at 40 . An earlier variation was known as a bill or letter of fair ('lettre de foire'). See, e.g., M. G. Des Marez, 'La lettre de foire au XIIIe siècle', (1899) 12 Revue de droit international et de legislation comparée 533; and A. P. Usher, 'The Origin of the Bill of Exchange', (1914) 22 Journal of Political Economy 566, at 566.

${ }_{78}$ De Roover, above n 15 , at 203. For the origins of the bills of exchange in medieval international trade practices, see also Boyer-Xambeu et al, above $\mathrm{n} 73$, at 17.

79 For a review of such views, see Huvelin, above n 28 , at $5-9$.

${ }^{80}$ De Roover, above n 35, at 12-17.

81 A possible fourth meaning, effectively overarching the second and third meanings, is any contract dealing with money or credit as opposed to merchandise (or logically, also to services). See Huvelin, above n 28, at 2.

${ }^{82}$ Origo, above $\mathrm{n} 11$, at 82 .

83 Permutatio is ' $[\mathrm{t}$ ] $\mathrm{k}$ e exchange of one thing for another, a barter. It differs from sale in that instead of money a thing is given as compensation. Permutatio is an innominate contract... not concluded by mere consent of the parties, as sale, but by an actual, real ... transfer of ownership from one party to another.'A. Berger, Encyclopedic Dictionary of Roman Law (1953), at 628. In Roman law, a contract whose nature is difficult to determine, but which is undoubtedly binding, as for example, where it falls on the border-line between two types, is an 'innominate' contract. See R. W. Lee, The Elements of Roman Law with a Translation of the Institutes of Justinian (4th edn, 1956), at 340-2. For the broader context of contracts in Roman law, see Geva, above $n 1$, ch 5, section 1, at 191-4. Cambium is not known in Roman law and thus is not defined by Berger. 
In its capacity as an exchange between two species of money, the contract of cambium covers three types of monetary exchange: ${ }^{84}$ the money change transaction, for the exchange of coins of different denominations or currencies, known as cambium minitum; a loan extended in one currency at one place, to be repaid in another currency at another place; and the dry exchange, namely, cambium siccum or 'secke or drye exchange', or in one form, cambium fictivum, or fictitious exchange. ${ }^{85}$

It is the second type of monetary exchange which gave rise to the bill or letter of payment. That is, the cambium or exchange contract is effectively a contract for the loan of money to be repaid in a currency and at a place other than those of the loan itself. ${ }^{86}$

Notwithstanding its substance as a loan, the exchange was not treated by medieval legal doctrine in those terms. ${ }^{87}$ Rather, in the eyes of medieval doctrine, the cambium or exchange contract involved a genuine exchange between two currencies at a rate reflecting a market price. It further involved the 'transportation' of the money from place to place. ${ }^{88}$. Hence, it was exempted from usury laws which regulated only the compensation for a loan, that is, the 'certain gain' for use of money, and neither the price for its transportation from place to place nor its exchange to a different currency. ${ }^{89}$ The cambium or exchange contract was treated as a simple and genuine currency exchange for which a charge may be imposed as determined at a rate expressing the different value of each currency.

Alternatively, the cambium contract was treated not as that of permutatio or barter, but rather that of an emptio-venditio, ${ }^{90}$ namely, of purchase and sale of money. Under that contract, 'absent' money was the thing purchased and sold; it was to be delivered elsewhere, at a specified future time, and for a price paid in 'present' money at the time and place of the conclusion of the transaction..$^{91}$ As in connection with permutatio, or barter, the transaction was not considered to be a loan, but rather constituted a genuine sale, and as such was

\footnotetext{
${ }^{84}$ See, e.g., Holdsworth, above n 11, at 126-7.

85 Thereunder, a loan extended in one currency at one place is ostensibly to be repaid in another currency at another place, as in the monetary exchange transaction between two species of currencies falling into the second meaning of cambium just discussed above. However, while in the transaction falling under the second meaning the contracting parties intend repayment to be carried out as contracted, this is not their intent in a transaction falling under this third meaning. Rather, the intent is to convert back repayment to the original currency and place of contract, with the lender profiting from the double conversion, receiving more than lent in the very same original currency of the loan. See in detail De Roover, above $\mathrm{n} 23$, and De Roover, 'Cambium ad Venetias-Contribution to the History of Foreign Exchange', in Kirshner (ed.), above n 15, 239.

${ }^{86}$ Interestingly enough, both Sayous ('Méthodes commerciales XV', above n 3, at 275) and De Roover (above $\mathrm{n} 85$, at 241 ) do not rtile out the possibility of repayment in the same currency (though always in another place), at least as an exception. And yet neither the former nor the latter analyses this possibility, either from the perspective of the application of usury law or otherwise.

${ }^{87}$ De Roover, above n 35 , at 19-21.

${ }^{88}$ Whether the instrument originated as a machinery for transfer, exchange, or the extension of credit, is discussed by Sayous, 'Méthodes commerciales des pays chrétiens de la Méditeranée de XIre et XIITe siècles', above n 3 , at 316-17.

${ }_{89}$ Regarding the application of usury laws two observations are to be made. First, a charge for a loan repayable in the carrency and place of the loan was usurious as it compensated the lender for the use of the money lent. Having involved the exchange between two sets of specific coins, even of different denominations, it was nevertheless not exempted from usury laws. Second, unlike Muslims (Geva, above n 1, ch 6, section 3.4, at 299-301) and in the footsteps of Jews (ibid., ch 7, section 4), Christians did not seem to regard the allocation to the borrower of the risk of loss in transportation as an unlawful gain to the lender in violation of usury laws. Hence, in the case of the Continental letter of payment, involving a loan to be repaid in a place and currency other than of the loan, usury laws did not apply. In any event, cost of 'transportation' was neither explicit nor a factor in the determination of the rate; the conventional wisdom is that it merely set the limits within which the exchange rate between the two currencies fluctuated: De Roover, above $\mathrm{n} 35$, at 11 , fn 1 (where the author is sceptical as to the accuracy of that conventional wisdom).

${ }_{90}$ In general for this term, see Berger, above n 83 , at 452 ('Emptio venditio').

91 De Roover, above $\mathrm{n} 35$, at 116 , as well as ibid., at 20 where he mentions another possibility, that of a sui generis contract. For the terminology of 'absent' and 'present' money, see also Boyer-Xambeu et al, above n 73, at 29 .
} 
exempt from usury laws. In this context, it was thus the genuine execution of this sale that gave rise to the bill of payment.

In any event, the terminology of 'present' and 'absent' money, denoting the two currencies involved in the exchange, was not limited to the emptio-venditio theory for the cambium contract. Rather it was equally applicable to the permutatio or barter theory, under which 'absent' money was exchanged or bartered (rather than purchased and sold as under the emptio-venditio theory) in the cambium contract for 'present' money.

Originally, bills were payable at medieval fairs, mostly those of Champagne. Fairs were, however, soon replaced by commercial centres. According to De Roover: ${ }^{92}$

By $1325 \ldots$ the rôle [sic] of the fairs of Champagne was played out... In the fourteenth and fifteenth centuries, the banking places of Europe were: Bologna, Florence, Genoa, Lucca, Milan, Naples, Palermo, Pisa, Siena, Venice, and the court of Rome in Italy; Avignon, Montpellier, and Paris in France; Barcelona, Valencia, and Palma de Mallorca in Spain; Bruges in Flanders; and London in England.... Paris declined shortly after 1400 ... as a result of the Hundred Years War, and its place was taken by the fairs of Geneva and, after 1465 , by those of Lyons. ${ }^{93}$ There were no banking places east of the Rhine, although the fairs of Frankfurt-on-the-Main began to emerge ... toward the end of the fifteenth century... ${ }^{94}$

Medieval bills were payable either at sight, at so many days after sight, at so many days from a specific date, or sometimes at the conclusion of a fair. ${ }^{95}$ Typically, however, a bill was paid at usance; it became due after a certain period of a fixed time determined by the mercantile custom for each pair of commercial centres. It could also be paid either at a slightly lower rate at half-usance or a slightly higher rate at double-usance. In each case, the amount to be repaid was fixed in advance; in theory it reflected the anticipated value of the loan in the currency measuring the repayment obligation according to the anticipated exchange rate upon maturity. However, in practice, it also included hidden interest charges to cover the use of the money actually lent. At the same time, not being based exclusively on the hidden interest charge, the rate of return to the lender was unknown, ${ }^{96}$ as it depended on how the exchange rate would swing. In fact, a lender could even lose money in case of unanticipated fluctuations. ${ }^{97}$ In other words, the transaction was speculative, which is another reason why usury laws did not apply.

Thus, the bill or letter of payment was a credit instrument facilitating the transportation of money from place to place, particularly in the execution of the payment obligation by the obligor of the exchange contract. It gave the obligor the use of the money between receiving it at one place and paying it at another. It further relieved him from the risk of loss in transit. In other words, the bill 'was not only a loan instrument but also a remittance contract that "transferred funds", or more accurately, effected payments between distant cities without any movement of precious metals between them'. ${ }^{98}$

\footnotetext{
92 De Roover, above n 15, at 205.

93 For a map titled 'The European Triangle of Exchange by Bills during the Heyday of the Lyons Fairs, 1533-75', see Boyer-Xambeu et al., above n 73, at 80 . Cities linked to Lyon, and in some places, also bilaterally, are Palermo, Messina, Rome, Lucca, Florence, Venice, Milan, Genoa, Antwerp, London, Rouen, Median del Campo, Lisbon, Seville, and Valencia.

${ }_{94}$ However, there may not be a universal agreement as to exact timing. Cf. Bergier, above n 10, at 116-29, speaking of the 'irresistible' ascent of German banks to hegemony in the financial life of Europe as occurting between 1480 and 1520 or 1530 .

95 R. De Roover, The Rise and Decline of the Medici Bank 1397-1494 (1963, 2nd print. 1968), at 110. Already in the early period Sayous noted the rarity of bills payable on demand. Sayous, 'Méthodes commerciales XV', above n 3, at 282. The sight bill did not become widespread until seventeenth century. See Boyer-Xambeu et al, above n 73, at 40 .

${ }^{96}$ De Roover, above n 35, at $55 . \quad 97$ De Roover, above n 85, at 243.

98 Munro, above n 53, at 543
} 
In practice, the bill or letter of payment served as an instrument for payment of debts incurred in commerce in a setting under which the caravan trade had been replaced by a sedentary commerce. In the former, the seller accompanied the goods. In the latter, the seller shipped them to a fair outside his place of business; that is, the merchant shipped goods to a foreign market in order to sell them there. To that end, he secured permanent representation in the foreign market by means of factors/agents, partners, or correspondents. In the sedentary commerce, the seller expected to be paid in a place and currency other than his own. To that end, the bill or letter of payment served as a facility for both the transmission of funds or payment from place to place as well as for the conversion of one currency to another. ${ }^{99}$

The document's roots are in a notarial instrument called an instrumentum ex causa cambii. It contained the authenticated signature of a debtor who thereby acknowledged receipt of money in local currency and promised to repay it elsewhere and in another currency. Such was the document originally used by Genoese bankers who usually promised to repay at the fairs of Champagne. ${ }^{100}$ Over the years, particularly in light of the close circle of signers involved in issuing such documents and their familiarity with each other, the notarial requirement was abandoned. Nevertheless, adherence to form was preserved: a bill or letter of payment had been required to use 'exact formulas' and 'customary wordings' and must have been handwritten by its issuer, rather than a scribe. ${ }^{101}$

In the process, the notarial promise to pay transformed itself to a signed order ${ }^{102}$ given to an agent or correspondent in the place of payment, who would then give the promise to pay by means of accepting the order. In terms of its contents, the bill or letter of payment was thus a written order given by the borrower, as the drawer of the letter. The drawer's order was addressed to a drawee. The drawer's order to the drawee was to pay to the payee, i.e. the recipient of the letter. The payment to be made by the drawee was denominated in the designated 'absent' currency, and was to be made at the designated place of payment. This payment was in repayment of the loan received by the drawer/borrower from the remitter/ lender, denominated in the 'present' currency, made at the place of the loan. To obtain payment, the payee was to present the document to the drawee either directly for payment, or first for acceptance and subsequently for payment. Endorsement was introduced in the course of the sixteenth century but did not become prevalent until the seventeenth century; hence, no practice of negotiation had been known, so that bills or letters of payment did not circulate. ${ }^{103}$ To that end, bills were issued -and not 'sold'104_by drawers/borrowers to remitters/lenders, who collected on them. ${ }^{105}$

It was once thought that, in the typical scenario, the letter or bill of payment was for the payment of a debt owed by the remitter/lender (located in one city) to the payee/receiver (located in another city). In this setting, the drawer and drawee were exchange bankers,

\footnotetext{
99 For a detailed analysis in a broad context, see De Roover, above n 5, at 42 .

100 De Roover, above n 15, at 203. ${ }_{101}$ Boyer-Xambeu et al, above n 73, at 30.

102 P. Huvelin, Essai historique sur le droit de marchés des foires (1897), at 553-4 speaks of an interim stage of two signed documents, one, being the foreign exchange contract, containing a promise to pay (directed to the remitter), and another, being the bill of payment, containing the order to pay in execution of the contract contained in the first document.

${ }_{103}$ De Roover, above n 15, at 221.

104 From a legal perspective, it is inaccurate then to refer to 'bills... bought and sold,' as referred to, for example, by De Roover, 'Banking and Credit', above $n 7$, at 10 . See also Boyer-Xambeu et al., above $n 73$, at 26 speaking of the drawer as a 'buyer of bills of exchange'. It is even more inaccurate to speak of 'negotiating commercial paper' as in De Roover, above n 95, at 110. All such terms suggest complete instruments being transferred from one person to another.

${ }^{105}$ For example, 'issue' is defined in BEA, above $\mathrm{n} 65, \mathrm{~s}$. 2, as 'the first delivery of a bill..., complete in form, to a person who takes it as a holder'. See also UCC, above n 65, \& 3-105(a).
} 


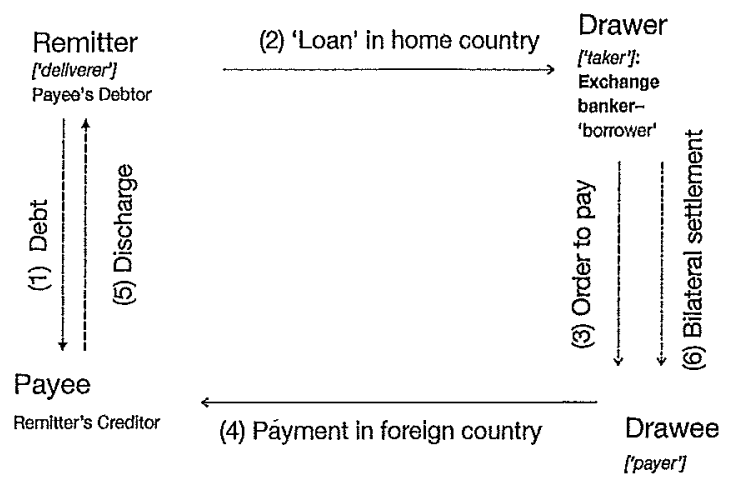

Figure 20.1 Four-party medieval bill of payment in the Continent-Remittance Bill.

respectively located in the place of the loan and the place of repayment. The drawee could thus have been an agent or a correspondent of the drawer. ${ }^{106}$ In this case, shown in Figure 20.1, the 'loan' given by the remitter/lender to the drawer/borrower was not a true extension of credit; rather, it was merely a device designed to render the drawee-exchange banker a debtor for the amount deposited in his hands by the drawer in order to carry out payment to the payee. Put another way, in this setting the bill or letter of payment was a contract for the transportation of money and of cambium and no more. As a contract for the transportation of money it operated then very much like the Islamic suftaj. ${ }^{107}$

This view on the typical setting for the original use of the bill or letter of payment understates and in fact overlooks the credit function of the instrument, and is not favoured anymore. This view possibly reflects a later period, in the course of the transformation of the bill of payment to the negotiable bill of exchange. Instead, current thinking envisages a more sophisticated use of the original instrument. Rather than as a remittance facility for an intercity payment from a debtor to a creditor, the original bill was viewed as a facilitator of trade-finance. As such, it was issued in connection with a borrower's obligation for the repayment of a loan in a foreign market that financed the purchase by the borrower, in his local market, of goods to be exported by him to that foreign market.

Under this second view, illustrated in Figure 20.2, the drawer was typically a seller of goods who sent them for sale in a foreign market. Originally, that foreign market was likely to be a fair. To finance his own procurement of the goods, the seller obtained a loan from a local exchange banker. In return for the money lent, the exchange banker received from the drawer-seller a letter of payment. Under that letter, the drawer-seller instructed a drawee, located in the foreign market to which the goods were to be shipped, to make payment to a payee located in that market. For his part, the exchange banker acted as a remitter; having delivered the money to the drawer-borrower, he sent the letter of payment issued to him by the drawer to the payee. .

106 On this point, Holdsworth, above n 11, at 128-37, following Huvelin, above n 28, at 5. See also C. H. S. Fifoot, 'The Development of the Law of Negotiable Instruments and the Law of Trusts', (1938) 59 Journal of the Institute of Bankers 433 , at 434.

${ }_{107}$ Except that Islamic suftaj did not involve currency exchange. See Geva, above n 1, ch 6, section 3.2, at 284-90 (as well as section 3.3, at 290-9). Briefly stated, the suftaj was an early Medieval Islamic payment instrument containing an obligation of a paymaster or his correspondent, acting under the instruction of a remitter, to pay at a place other than that of the issue of the document. It was used for payment or transfer of funds between two places, possibly but not exclusively, from a debtor to a creditor, particularly over routes serving permanent business connections. 


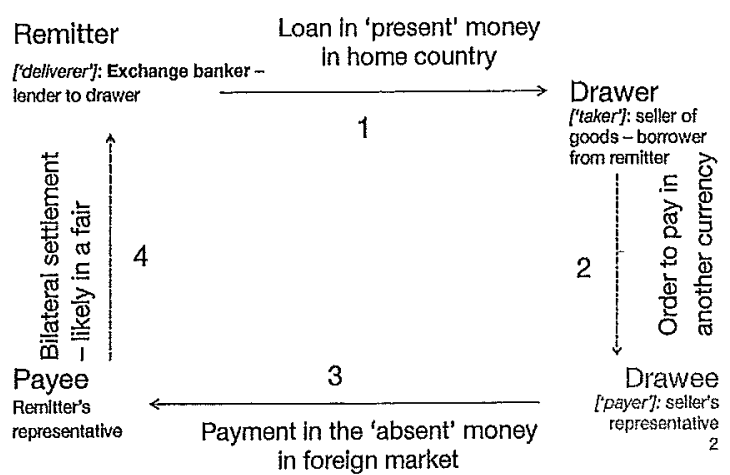

Figure 20.2 Four-party medieval bill of payment in the Continent-Export (trade) Bill.

The drawer-seller used the actual loan proceeds to buy the goods at his own place; subsequently, he shipped the goods to the foreign market. Having anticipated receipt of payment for the goods in the foreign market, in his loan agreement with the exchange banker, the seller undertook the repayment of the borrowed money in the foreign market. ${ }^{108}$ As explained below, the bill was stated to be payable in a territorial unit of account of one of the cities, rather than in the actual money of payment.

In this setting, the seller drew the bill or letter of payment on the person who was to sell it on a retail basis in the foreign market, such as a fair. In the letter, the drawer-seller instructed the drawee to pay. Where the drawer-seller knew the identity of his own foreign buyer in advance, prior to the procurement or at least shipment of the goods, the drawee who was instructed to pay by the drawer-seller could also be the buyer. Such would be the case for example where the drawer-seller was a wholesaler in one city who sold the goods to a foreign retailer (in another city) who was to resell the goods in the foreign market, in which case, the foreign buyer could act as the drawee.

However, in most cases, the identity of the buyers was not known in advance; that is, the sale at the foreign market was to be carried out not by a buyer from the drawer-seller, but rather by the drawer-seller's own agent, principal, partner, or correspondent. Under such circumstances, the drawee, who was instructed by the drawer-seller to pay the payee, was the drawer-seller's agent, partner, or correspondent in the foreign market. He was to be paid by the buyers of the goods shipped by the drawer-seller, and use the money received from them for the repayment of the loan originally taken by the drawer-seller from the exchange banker.

Similarly, the designated payee was an agent, principal, partner, or correspondent of the lender in the foreign market. Upon receiving the letter, the designated payee would present it to the drawee for acceptance, and in due course, upon maturity, for payment. The bill was most likely drawn payable at maturity set by reference to the applicable usance, ${ }^{109}$ so as to target maturity to coincide with the availability of the proceeds from the sale. By reference to the money (or more broadly, value) for which the bill was issued, the exchange bankerlender was the 'deliverer', the drawer-borrower was the 'taker', the drawee was the 'payer', and the lender's correspondent or agent was the 'payee'. ${ }^{110}$ Presumably, any profit from the sale formed part of the drawee's commission to the extent that the amount realized was higher than the sum repaid to the payee. It was thus left in the hands of the drawee, acting for the seller-drawer. Any balance, could either be reinvested, for example in the purchase

108 See, e.g., De Roover, above $n$ 35, at 29-31 and 43-5.

109 For this term, see text following $\mathrm{n} 95$ above.

110 See, e.g., Boyer-Xambeu et al, above $n$ 73, at 30 . 
of goods in the place of repayment, or repatriated to the seller-drawer's place, under the same mechanism. The sum paid to the payee could be repatriated to the remitter, with further profit, by having the payee lending it, against a new 'reverse' bill of payment given by a local borrower, namely an exporter in the payee's place, who was to ship goods for sale at the remitter's place. On that 'reverse' bill, the borrower-exporter would instruct a drawee at the remitter's place, such as his (the exporter's) own agent, to pay to the remitter on the original bill. In the process, the remitter and payee on the original one reversed their roles, and respectively became the payee and the remitter on the 'reverse' one. ${ }^{111}$

It may be thought that the exchange transaction relieved participants from risks associated with counterfeit coins, to which they would have been exposed, had they been dealing with foreign currency with which they were unfamiliar. ${ }^{12}$ This is, however, a misconception; generally speaking, ${ }^{113}$ coins of the diverse currencies circulated throughout the entire Continent and, as a rule, merchants were familiar with them. Hence, the essence of the exchange was not a change designed to achieve payment in a particular currency as money of payment.

Rather, 'exchange by bills concerned moneys of account'. ${ }^{114}$ In practice, bills of payment issued and payable in fairs indicated both units of accounts of the 'present' and 'absent' money. ${ }^{115}$ They thus specified the amount paid by the remitter in the unit of account of one place ('present' money) and the amount payable by the drawee in the unit of account of the other place ('absent' money); at the same time, they did not specify money of payment by either party. Moreover, the territorial unit of account in which the bill was payable, that is, the amount of 'absent' money, was not necessarily that of the place of payment by the drawee; rather, between each pair of cities, 'the sum for which the bill was a payment order was always drawn in the exchange money of one of the cities concerned, regardless of the direction of the remittance. ${ }^{116}$

As a rule, a 'payment fair' (or central exchange fair), which was effectively the medieval money market, took place next to each merchandise fair. ${ }^{117}$ Payment procedures were not static. They developed over time and were subject to local variations. ${ }^{118} \mathrm{~A}$ developed payment procedure in the Fairs of Lyons in the fifteenth and sixteenth centuries consisted

${ }^{111}$ J. S. Rogers, The Early History of the Law of Bills and Notes: A Study of the Origins of Anglo-American Commercial Law (1995), at 32-6.

${ }_{112}$ Cf, Holdsworth, above $n 11$, at 128 , speaking of the exchangers as coin experts.

113 Though not without exceptions: Boyer-Xambeu et al, above $n$ 73, at 77.

114 Ibid., at 70. "The money of account is the currency in which an obligation is measured... The money of payment is the currency in which the obligation is to be discharged': Woodhouse Ltd. $v$ Nigerian Produce Ltd. [1971] 2 QB 23, at 54 per Lord Denning MR (original emphasis). For money of account in the Middle Ages, see P. Spufford, 'Appendix: Coinage and Currency', in Postan et al. (eds), 576, at 593.

115 For this terminology, see text accompanying $n 91$ above.

116 Boyer-Xambeu et al, above $n$ 73, at 83 , who further note (ibid., at 82 and 94) how this facilitated 'the systematic enrichment of the exchange bankers' through a 'double exchange transaction' which they explain, ibid., at 82-91 and 94-100. Briefly stated, the mechanism was premised on the fact that in terms of the currency of the amount remitted ('pretium' or 'moveable'), the amount in which the bill was drawn payable ('res' or 'certain') was lower in the place of origin than in the place of destination. Accordingly, for example (ibid., at 84-5), a Florence remitter would deliver the equivalent of 64 écus (the 'moveable') per one marc (the 'certain') to the drawer who needs this sum in Florence and who would order the drawee (the drawer's associate) in Lyons, under the original bill, to pay the marc equivalent, as specified in the bill (according to the same rate of one marc equals 64 écus), to the payee in Lyons. The payee is associated with the remitter; he would be instructed by the remitter to deliver the sum received, under which one marc in Lyons is worth 65.5 écus, to a borrower in Lyons. Under a return bill, the Lyons borrower would order another person, associated with him, in Florence (and acting as a drawee on the return bill), to pay to the original Florence remitter an amount denominated in marcs, for which he paid in Lyons an equivalent denominated in écus, at the rate of 65.5 écus per marc. The original Florence remitter had thus lent at the rate of 64 écus per marc and received an amount with which he can purchase 65.5 écus per marc. His profit is then 1.5 écus. In this case, the marc and the écus are the relevant units of accounts. For both bills, namely the original (remitting funds from Florence to Lyons) and the return one (remitting funds from Lyons to Florence), the écus is the 'present' money while the marc is the 'absent' money.

117 See ibid., at 70-91. See also De Roover, above n 35, at 74-82.

118 See Usher, above $\mathrm{n} 3$, at 110-33. See also Huvelin, above n 102, at 534-93. 
of three stages, each taking place on a different day. ${ }^{119}$ These stages were acceptance (first day), exchange (third day), and settlement (sixth day). On the day of acceptance all participants would meet; payees would present bills payable in an amount denominated in the territorial money of the fair on respective drawees. In the next one or two days, participants drew up balances. A conto, namely a set of exchange rates, was determined on the day of exchange. These exchange rates were designed to apply to future transactions in the aftermath of the fair as well as facilitate further exchanges at the fair itself until day of settlement, so as to allow participants to improve on their exchange balances. Finally, on the day of settlement, all transactions falling due in the fair were settled. Each participant would endeavour to pay his debts by either cancelling out mutual debts or by substituting his claim on another participant; a creditor who accepted this substitution of debtors did so at his own risk. Substitution was by delegation. Thus, where $X$ owed $Y$ who owed $Z$, $Y$ would instruct $X$ to pay $Z$. Execution of this delegation was 'perfect': 120 upon the agreement of both $X$ and $Z, Y$ was discharged. Unless $X$ was in a position to cancel this debt by either offsetting it against a debt in the same amount owed to him by $Z$, or by replacing himself by means of a delegation to his own debtor, he would be in the same position as any debtor who was unable to cancel a debt. A debtor unable to pay a debt by cancellation or delegation would try to defer payment to the next (succeeding) fair, for which he had to pay a fee. Debts that could not be settled in any of these ways had to be settled in specie, that is, in a specific currency, serving as money of payment.

This procedure is the forerunner of organized multilateral interbank clearing. Its operation was premised on bilateral netting. However, it allowed the substitution of debtors by agreement and was the genesis of interbank clearing operating in an organized multilateral
setting.

The mechanism was workable only in the context of functioning networks of merchants and bankers. ${ }^{121}$ In fact, in practice, as indicated, the banking network was superadded to an existing mercantile network. Also, in this setting the letter of payment was more than an instrument for the transportation of money and the conversion of currency, and in which the extension of credit was a mere incident of the transportation of money. Rather, in this setting, its use as a credit facility was a distinctive cardinal feature of the mechanism. Thus, the drawer was a 'true' borrower and the remitter was a 'true' lender. As for the nature of the loan under medieval law and practice, the shipper-drawer-borrower was absolutely and strictly liable to repay the loan, or more specifically, the amount of the instrument, regardless of the safe arrival of the goods to their destination, and irrespective of whether their sale generated adequate proceeds. In this respect it was unlike the older 'sea loan' for whose repayment the borrower was not responsible in case of the loss of the goods. ${ }^{122}$

Certainly, for such a mechanism to work, the drawer/exchange banker in the first setting (that of a straightforward remittance from place to place) and the remitter/lender in the

\footnotetext{
119 The ensuing discussion draws on Boyer-Xambeu et al, above $n$ 73, at 91-4.

120 For the perfect execution of the delegation under Roman law, see Geva, above

Briefly stated, the delegation is an order given under Roman law, see Geva, above n 1, ch 5, section 6, at 214-23. pay to, or assume an obligation towards, a third person ('delegatee'). Where the delegant (Y) is do be delegated') to the delegatee $(\mathrm{Z})$ upon the acceptance by the person to be delegated $(X)$ delegant $(Y)$ is discharged towards delegatee $(\mathrm{Z})$, the execution of the delegation is said to be be delegated $(X)$ who thereby becomes liable to the 121 In the words of De Roover, above 5 , 5 is said to be perfect.
In

perhaps the major problem of [the] sedentary ,.. 43 , "How to get satisfactory representation in foreign parts was of efficient and honest representatives.'

122 For the various representatives. alluded to in the text above by referring to the sea loan at 55-9. Huvelin, above $n$ 28, at 2 mentions the distinction borrower, does not assume operational risks. See loan as 'prêt d la grosse' in which the 'transporter', namely the milieu du XIII siècle', (1929) 95 Revue des études historiques 391, at 405-7.
} 
second setting (that of a remittance to finance the export of goods) ${ }^{123}$ envisaged some use, at the place and currency of payment, for the actual funds to be repaid at the place of payment. Such use may have been a profitable contract for the repatriation of the funds. ${ }^{124}$ Alternatively, the drawer and drawee in the first setting, and the remitter and the payee in the second, were correspondents, with mutual dealings going back and forth in both directions.

The bill of payment was a flexible facility that could be used to fulfil various functions. The two functions already mentioned were first, a remittance to a distant creditor, and secondly, trade-finance, i.e. the repayment of a loan for the purchase of goods with the proceeds of the sale of the goods in a foreign market. While as stated above, it is likely that the trade-finance function was predominant, it does not follow that the remittance facility did not exist at all. In the remittance setting, the exchange banker acted as a 'borrower; ; 125 in the trade-finance scenario, he acted as a lender. Either way, the medieval exchange banker neither accepted deposits-other than for transmission-nor lent money out of deposits; rather, he either 'borrowed' for transmission or lent out of his own capital for transmission. It follows that unlike medieval transfer and deposit banking, discussed in Section II above, medieval exchange banking did not involve financial intermediation and unlike modern commercial banking did not thrive on the 'spread' between interest paid on deposits and received on loans. Rather, the medieval exchange banker acted as money-transmitter; his profit flowed from the use of the money in the course of its transit (when he acted as a borrower) and from the exchange and hidden interest rates (when he acted as a lender).

The entire exchange banking enterprise could be profitable only in connection with large capitalization as well as an existing trade network. The latter was put to use for the extra task of transmission and receipt of funds lent or borrowed elsewhere rather than established specifically for the purpose of transmission. Medieval exchange banking was not a retail operation; a merchant participating in the transaction ought also to act on an international scale. Thus, as a 'lender' to the drawer-banker in the first scenario (that of a straightforward remittance from place to place), the merchant must have dealt with a foreign creditor, while as a borrower from the remitter-banker in the second scenario (that of a remittance to finance the export of goods), the merchant must have been a shipper of goods to a foreign market where he either must have dealt with a buyer or, more likely, had a representative.

However, as an adaptation of the function of remittance to a distant creditor, the bill of payment could be utilized also on a smaller scale, for what we call today a traveller's letter of credit. ${ }^{126}$ For example, the remitter may be a traveller, student, or pilgrim who gave funds to the drawer, an exchange banker at the place of departure in the currency of that place, with a view to receiving their equivalent at the place of the destination in the currency of that place. Such payment was to be received by the remitter/payee from the agent, principal, partner, or correspondent of the drawer, acting as a drawee. In such a case, the payee was the remitter; however, this particular use could also become a four-party facility, where a

123 For the two settings, see text accompanying nn 106-8 above

124 See text accompanying nn 109-11 above.

125 This does not preclude the possibility of lending the funds for transmission, which would then be a separate transaction under which the remitter-payer will have to pay the drawer separately in the place and currency of the loan.

126 See, e.g., De Roover, above n 35, at 44. Ibid., at 90, he describes the letter of credit and bill of exchange as twin documents, with the former usually issued in favour of a non-merchant and payable against a discharge note ('quittance'). 
remitter forwarded funds to a relative in the point of destination. Moreover, the letter of credit was not limited to personal affairs of individuals. Rather, as happened, for example, at the times of the crusades, 'Popes, kings and princes' extensively used letters of credit instructing payments in faraway lands. ${ }^{127}$ Such letters may have invariably been four-party facilities.

In fact, any bill of payment could be a two-, three-, or four-party facility. Stated otherwise, in each case, the drawer and the payee, and/or the remitter and the payee, could be the same person. As a mere machinery for the transmission of funds from place to place it could even comprise four units of the same legal entity. However, for the completion of the picture, the ensuing legal analysis supposes the involvement of four participants, namely a remitter (or deliverer; lender), drawer (or taker; borrower), drawee (who may become an acceptor upon agreeing to pay), and payee.

\section{The Bill of Payment: Legal Relationships}

Under modern law, a remitter in possession of a bill of exchange may sue parties liable on it. The basis of this right is his ownership of the instrument ${ }^{128}$ rather than any specific statutory provision. ${ }^{129}$ Otherwise, under modern negotiable instruments legislation, liability on a dishonoured bill of exchange inures to the benefit of the holder. ${ }^{130}$ The holder is either the bearer of an instrument payable to the bearer, or the named payee or endorsee of a bill payable to order while he is in possession of it. ${ }^{131}$

The general rule is that a signature is an absolute requirement for liability on a bill of exchange. ${ }^{132}$ One exception is under French law, which allows the holder to recover from the drawee, on the basis of la provision, that is, what the drawee owes the drawer, even without an acceptance. ${ }^{133}$ Otherwise, a drawee incurs liability to the holder only by signing as an acceptor. ${ }^{134}$ The holder always has the option of suing the drawer as well as any endorser. ${ }^{135}$ A drawer who pays the holder has recourse against the acceptor. ${ }^{136}$

127 See, e.g., Usher, above $\mathrm{n} 77$, at 569.
128 For the remitter as the first owner of an instrument, see F. K. Beutel, 'Rights of Remitters and Other Owners not within the Tenor of Negotiable Instruments', (1928) 12 Minnesota Law Review 584; and W. E. Britton, Handbook on the Law of Bills and Notes (2nd edn, 1961), at 179. See also B. Geva, "The Autonon,

Obligation on Bank Drafts and Certified Checks', (1994) 73 Canada Bar Review 21, in $\$ 3-103(a)(15)$ ), while in

129 An exception is UCC, above n 65, Art. 3, under which a remitter (defined in possession of the instrument, is said by Official Comment to $\$ 3-301$ to be a non-holder in possessim.

\$ 3-301(i) 'has the rights of a holder' so as to be entited to enforce the lns, Arts. 16-19 and 40; UCC, above n 65

130 BEA, above n 65, s. 38(1); cf. Geneva Bills Convention, above n 65, A

§ 3-301(i); UNCITRAL Bills Convention, above in 65, Abve n 65, Art. 16; UCC, above n 65, \$ 1-201(b)(21)(A);

131 BEA, above n 65, s. 2; Geneva Bills Convention, above

UNCITRAL Bills Convention, aboven 65 , Alls Convention, above n 65, Arts. 7-8; UCC, above n 65, \& 3-401;

132 BEA, above n 65, s. 23; Geneva Bills Conver

NCITRAL Bills Convention, above

133 For la provision in French law, see, e.g., C. Gavalda and J. Stoufflet, Instruments instruments', in U. Drobnig J. Stoufflet (7th edn, 2009), at 105-14; and for a summary, see P. Ellinger, Negotiable Instruments', in Unactions and and K. Zweight (eds), International Encyclopedia of Comparative Law. Vol 9: Commercial Transactions and Institutions, ed. J. S. Ziegel (2000), ch 4, at 110-13. See also G. Ripert and R. Roblot, Traite de drots de commerce (13th edn, 1992), at 181-6. For a more extensive analysis, see P. Lescot and R. Roblot, Les effets de commerce (1953), vol. 1 , at 389 .

134 , Cf. Geneva Bills Convention, above n 65, Arts. 21 and 28.

135 In principle, a cause of action against the drawer and endorsers is avallable to the holder upon compliance 列 with formalities, such as presentment to and dishonour by the drawee, and notice given to parties to be $65,8 \S 3-414$, See BEA, above n 65, s. 55; Geneva Bills Convention, above n 65, Arts, above n 65, Arts. 38 and 44.

3-415, and Art. 3 Part 5 ('Dishonour'); UNCI 
A remitter does not sign the bill; as such, he is not liable on it. Whether he can be sued on the transaction for which the bill was given once the bill has reached the payee depends first on whether the bill was issued to the payee in payment of a debt owed by the remitter to the payee. Second, it depends on whether the payee had taken the bill of exchange in conditional or absolute discharge of the debt owed to him by the remitter. Only where a bill is taken in conditional payment is recourse on the underlying transaction available to the holder against the remitter. ${ }^{137}$

This section will now endeavour to trace the foundations of the rules set out above in the medieval application of principles derived from Roman law. Briefly stated, Roman law dealt with the delegation order given by a debtor, to his own debtor (paymaster) to pay to the debtor's creditor. Upon receiving the delegation order, the paymaster does not automatically become obliged to pay the creditor. Nor does the paymaster's agreement to comply with the instruction necessarily discharge the debtor's debt to the creditor. Rather, it is payment by the paymaster which discharges both his own debt to the debtor and the debtor's debt to the creditor. Accordingly, a paymaster who declines to follow the delegation order remains indebted to the debtor who remains indebted to the creditor. ${ }^{138}$

At the same time, execution of the payment order by means of the paymaster's agreement is fully recognized; Roman law facilitates both the imperfect and perfect execution of the debtor's delegation order, instructing the paymaster to pay the debtor's debt to the creditor. ${ }^{139}$ As pointed out below, such execution may or may not discharge the debtor's debt to the creditor.

Furthermore, Roman law facilitates the issue of a delegation order by a paymaster to his correspondent acting as his own paymaster. ${ }^{140}$ Such 'sub-delegation' may have been the model for the Islamic suftaj, under which, in connection with the transfer of funds from one place to another, a paymaster at the point of origin instructed a correspondent at the point of destination to make the payment. ${ }^{141}$ Under some circumstances a sub-delegation may also explain the legal effect of the letter of payment.

Thus, in circumstances under which the letter of payment was a mechanism for the payment of a debt owed by the remitter to the payee, the letter corresponded to the subdelegation of the remitter's delegation order to the drawer. In this context, the remitter was the first delegant, instructing the taker-borrower to pay to the payee; in turn, the takerborrower, being in effect the paymaster-drawee in the first transaction, upon the subdelegation, becomes the delegant-drawer of the letter of payment instructing the drawee under the letter of payment to pay to the payee.

The distinction between the imperfect and perfect execution of the delegation order was expressed in the effect of the acceptance by the drawee, upon which he became liable to the payee, on the obligation of the debtor to the creditor. Thus, upon an imperfect execution, the order-giver, that is the debtor, remained liable to the payee-creditor even after acceptance by the order-recipient, that is, the drawee. Conversely, in the perfect execution of the delegation order, the acceptance by the drawee discharged altogether the debtor. The two classic means for the imperfect execution are the receptum and constitutum. ${ }^{142}$ At the same time, the novation by stipulation ${ }^{143}$ was the classic mode for the perfect execution. ${ }^{144}$

\footnotetext{
137 The distinction is codified in UCC, above $\mathrm{n} 65$, Art. 3, § 3-310. A good common law discussion is In re Charge Card Services Ltd. [1988] 3 All ER 702, 707 (CA).

138 See, in general, Geva, above $n 1$, ch 5 , section 3 , at 201-8.

139 See, in general, ibid, ch 5, section 4, at 208-10. ${ }_{140}$ See, in general, ibid., ch 5, section 10.3, at 244-6.

141 The suftaj is fully discussed in ibid., ch 6, section 3, at 277-301.

142 Fuily discussed in ibid., ch 5, section 5, at 210-14.

143 Fully discussed in ibid., ch 5, section 6, at 214-23.

144 See Figures 20.1 and 20.2 in Section III above for an illustration of the principal features of payment mechanisms under Roman law.
} 
Receptum argentarii ${ }^{145}$ was limited to the case of a promise undertaken by a banker (argentarius), acting under the instruction of his client, to perform towards a third party, on a fixed date. The banker's obligation was entirely autonomous, namely, free of defences that may have been available to the client against the third party, and enforceable by the third party against the banker even when the client's obligation to the third party was invalid. ${ }^{146}$ At the same time, the banker's undertaking to the third party did not affect the client's own original obligation to the third party; that is, until satisfaction, both obligations to the third party, that of the client and his banker, subsisted side by side, and were enforceable by the third party.

The constitutum was a promise to pay an existing debt on a stated date and at a stated place. The existing debt was either that of the promissor or of another party. The former was a case of constitutum proprii and the latter was that of constitutum debiti alieni. ${ }^{147}$ The promise given under the constitutum was that of an assurance as to the availability to the creditor on the due date of the sum owed under the original debt. No formal requirements were to be met by the promise in order to be binding; it could be given orally, in writing, in absentia, and even by messages; most frequently, it was given by means of a letter sent (rather than directly delivered) by the promissor. ${ }^{148}$ The rationale underlying the constitutum promise was that of modification to the promise to pay an existing debt, by an additional promise simultaneously given at the time the loan was extended.

Like the banker's promise on receptum argentarit, the constitutum promise did not lead to the novation of the pre-existing debt and did not supersede it; it gave the creditor the option of an alternative remedy. Contrary to the stipulation discussed further below, the constitutum promise was given at the initiative of the party to become liable on it; and not in response to a creditor's question; as such, and contrary to the receptum argentarii, the constitutum promise was not presumed to be autonomous and free of defences arising from the pre-existing debt, including as to its validity. However, the lack both of a novatory effect and of autonomy may have been based on the intention of the parties, and hence were more certain to exist in constitutum proprii than in constitutum debiti alieni; the latter might nevertheless be taken to be intended both to discharge the original debtor, so as to have a novatory effect, and to be autonomous in relation to the original debtor's pre-existing debt. ${ }^{149}$ And yet, in the absence of novation, it was not so obvious what legal doctrine could implement such intent.

${ }^{145}$ For a comprehensive discussion, see G. Platon, Les banquiers dans la législation de Justinien, Pt 1 (1912), at 43 , ch 2 'Receptum argentarii', as well as ensuing chapters, dealing with the relationship between the receptum argentarii and various other legal obligations.

${ }_{146}$ Or else, as put by Platon, ibid,, at 46 , the receptum does not require any 'causa'; it thus stands on its own absolute or abstract terms.

147 See Berger, above n 83, at 410; H. Coulon, Droit romain: Du constitut debiti alieni (1889); A. Philippin, Le pacte de constitut: actio de pecunia constituta (1929); and J. Déjardin, L'action pecuntae constitutae (1914). See also Platon, above n 145, at 164, ch V.bis, 'Histoire et rôle du constitut', and E. Guillard, Les banquiers athéniens et romains-trapezzites argentarii, suivis du Pacte de constitut en droit romain (1875), at 104-30.

148 A point highlighted by Platon, above $\mathrm{n} 145$, at 191 , who calls such a mode of communication by letter, 'epistola', and notes the similarity of the letter to the subsequent bill of exchange. According to Berger, above $n$ 83, at 454, espitula is a private letter that becomes the property of the addressee upon receipt: 'Certain agreements, primarily consensual contracts... might be concluded by letter (per epistulam)'.

149 On this point see, in particular, Philippin, above n 47 , at 88-93, where the Praetorian basis of the constitutum is cited as the justification for reliance on the parties' intention. For the role of the intention of the parties, see also E. Bodin, 'Des effets du pacte de constitut', (1866) 12 Revue historique de droit français et étranger 209. For a detailed analysis as to whether particularly the constitutum debiti alieni is to be taken as substituting the debtor, adding a co-debtor, or giving rise to a guarantee, see J. Déjardin, L'action pecuniae constitutae (1914), at $67-98$. 
A most frequently used route for a perfect execution of the delegation was stipulatio. ${ }^{150}$ Contrary to both the receptum and constitutum, the stipulatio served as a model for the perfect execution of the delegation order. It was an oral, solemn contract concluded in the form of a face-to-face exchange of a question and an answer between two persons who, on the basis of the successful completion of the exchange, became parties to a contract. It was a formal, verbal, unilateral, and stricti juris contract; ${ }^{151}$ its formation required a question to be asked by the stipulator, a would-be promissee-creditor, immediately followed by an affirmative answer given by the person to whom the question was directed, who thereby became the promissor-debtor. The two parties had to be in the presence of each other and the question and answer had to be spoken; furthermore, 'there should be precise correspondence between question and answer.' ${ }^{152}$ Typically, in our setting, the drawee's agreement to abide by the drawer's order by means of incurring a stipulatory obligation to the payee discharged the original obligation of the drawer to the payee and was autonomous with respect to it, namely, free of defences that might be available to the drawer against the payee.

Finally, there was the alternative of cessio. ${ }^{153}$ In this context, a debt owed by the drawee to the drawer was transferred by the drawer to the payee. The payee, as an assignee, was to enforce against the drawee the debt owed by the drawee to the drawer, and as such was subject to defences available to the drawee against the drawer.

Indeed, Roman law could facilitate the payment to a distant party, ${ }^{154}$ as such it was capable of producing a mechanism similar in function to the letter of payment. However, in Roman law there was no role for the written document. As well, the classic stipulatio was unable to support a contract between two distant parties. Moreover, in the course of the first millennium $\mathrm{CE}$, key concepts such as the stipulatio, receptum, and constitutum ceased to exist as avenues for recovery. ${ }^{155}$ Also, notwithstanding Roman law's recognition of cessio in the sixth century $\mathrm{CE}$, strong doubts as to its effectiveness to transfer rights persisted in civilian legal systems which drew on the Romanist tradition until the middle of the nineteenth century. ${ }^{156} \mathrm{It}$ is against this background that the possibility of direct derivation of the bill of exchange from Roman law was forcefully denied by Holdsworth. In his view, "it is clear that there is nothing in Roman law which in any way resembles the bill of exchange'. Indeed, he acknowledged, '[n]o doubt the adstipulatio, the delegatio, and the novatio could be made to fulfil some of the functions fulfilled by the bill of exchange; but we cannot find in the classical texts any institution which resembles it in form, or in mode of operation. ${ }^{\text {.157 }}$

An apparent obstacle in Roman law was its strict privity requirements. However, in the course of the twelfth and thirteenth centuries these requirements had been under attack. The scholarly view that prevailed at the end of the fifteenth century built on developments in canon and some local laws, as well as on the need to satisfy evolving societal and mercantile requirements. This view allowed a third-party beneficiary, claiming under an assignment from the promissee, to sue the promissor, provided the latter took an oath confirming his promise. Ultimately, in the course of the seventeenth and eighteenth

150 For a definition, see Berger, above n 83, at 716 and for analysis, see, e.g., Lee, above n 83, at 298-304 and B. Nicholas, An Introduction to Roman Law (1962), at 193-6.

${ }_{151}$ For classification of contracts see concluding paragraphs in Geva, above $\mathrm{n}$ 1, ch 5, section 1, at 191-4.

152 Lee, above n 83, at 298. See also Nicholas, above n 150, at 193. Berger, above n 83, at 716 ('Stipulatio') states that ' $[t]$ he answer had to agree perfectly with the question; any difference or restriction (addition of a condition) made the stipulatio void'.

${ }_{153}$ Fully discussed in Geva, above n 1, ch 5, section 9, at 233-41.

154 See ibid., ch 5, section 10.3, at 244-6. ${ }_{155}$ See ibid., ch 5, section 8, at 229-32.

156 See ibid., ch 5, section 9, at 233-41. ${ }^{157}$ Holdsworth, above n 11, at 132-3. 
centuries, courts came to recognize a direct right of the beneficiary against the promissor. ${ }^{158}$

A scholarly view that precipitated the culmination of that process relied on the direct right of the holder of a bill of exchange or note payable to the bearer against the issuer of the instrument. ${ }^{159}$ However, the process was not unidirectional: the recognition of the payee's right against the drawer had evolved during the Middle Ages in a legal environment in which the walls of privity were crumbling, particularly through the use of cessio and agency.

The ensuing analysis will demonstrate the manner in which the adaptation of principles derived from Roman law underlay the legal relations among participants in the bill of payment transaction. In fact, this was acknowledged by Holdsworth. ${ }^{160}$ Stated otherwise, medieval lawyers used terminology derived from Roman law either by analogy, or by varying its contents.

Among the four parties to the letter of payment transaction, privity existed between the remitter and drawer, the drawer and the drawee, and the remitter and the payee. Thus, the remitter delivered the money to the drawer for the delivery of an equivalent sum of money denominated in another currency to the payee. The drawer and drawee were correspondents, if not a principal and agent. ${ }^{161}$ In the remittance scenario the drawer and drawee acted as fellow bankers. In the trade-finance setting they acted as fellow merchants. In the remittance setting, the remitter and the payee might respectively be a debtor and creditor under a pre-existing transaction. Alternatively, in the more prevalent trade-finance setting, the remitter and payee acted as bankers. ${ }^{162}$

The bill of exchange transaction was completed by the drawee's payment to the payee. At that point, the drawer was discharged towards the remitter; the drawee was either discharged towards the drawer or became owed by the drawer. In the remittance scenario, the remitter was discharged towards (his fellow merchant) the payee-creditor. Fellow bankers, namely the drawer and the drawee in the remittance scenario and the remitter and payee in the trade-finance setting, would typically make periodic settlements on bills going in both directions, possibly in a fair as outlined in Section III above. For their part, the drawer and drawee acted in the trade-finance setting as fellow-merchants; the drawer was to settle either for a single transaction, or again, for a balance reflecting a periodical activity, by means of another remittance, made from the place of the indebted party to that of the creditor.

The payee was not in privity with the drawer; he might nevertheless be in privity with the drawee-acceptor. At the same time, the remitter was in privity with the drawer but not with the drawee-acceptor. According to De Roover, under medieval law, privity requirements still persisted; thereunder, the drawer was solely liable to the remitter and the drawee might

${ }^{158}$ See J. Hallebeek, 'Roman Law', in J. Hallebeek and H. Dondorp (eds), Contracts for a Third-Party Beneficiary: A Historical and Comparative Account (2008) 8; J. Hallebeek, 'Medieval Legal Scholarship', in Hallebeek and Dondorp (eds), 21; H. Dondorp, 'The Seventeenth and Eighteenth Centuries', in Hallebeek and Dondorp (eds), 47; and J. Hallebeek, 'Tus Quaesitum Tertio in Medieval Roman Law,' in E. J. H. Schrage, Ius quaesitum tertio (2008) 61.

${ }_{159}$ See Dondrop, above n 158, at 67 and $68 . \quad 160 \mathrm{rbid}$.

161 Where they are mere correspondents, namely, neither the same person nor a principal and agent, Huvelin, above $n 28$, at 12-13 rationalizes their relationship as premised on a commenda, that is, a form of partnership, under which the drawer puts the drawee in funds in performance of a joint business purpose, viz, their delivery to the payee. In theory at least, in the trade-finance setting, they may be a debtor and creditor, for example where the drawee bought the goods from the drawer.

162 Either way, as indicated at the end of Section III above, the four parties to the bill of payment are the remitter (or deliverer; lender), the drawer (or taker; borrower), the drawee (who may become an acceptor upon agreeing to pay), and the payee. Charts illustrating the transaction flow in each scenario are incorporated in this chapter. The reader may follow them in pursuing the discussion which follows. 
be liable only to the payee. Between these two beneficiaries, it was however the remitter and not the payee who was the 'master' of the bill. ${ }^{163}$ Though he was not in privity with the drawee, the remitter might revoke payment even after acceptance by the drawee, ${ }^{164}$ presumably any time until maturity. This would appear to have posed a serious limitation on the payee's right against the acceptor, except that this subjection to the revocation power of the remitter fitted very well with De Roover's view as to the position of the remitter as a banker-lender associated with the payee-rather than as a debtor of the payee. ${ }^{165}$

De Roover's analysis treats the bill of payment transaction as a mechanism for the execution of the exchange contract. Thus, there was an exchange contract to which the remitter and drawer were the parties. In turn, though the letter of payment was issued by the drawer, it was the drawee who might be liable to the payee thereon. Accordingly, though derived from the same transaction and yet effectively from two separate contracts in relation to it, the drawer's obligation and that of the drawee were 'two species of obligation' which were 'conceptually and practically distinct'. ${ }^{166}$ Their only link was the mutual impact of their performance. Thus, payment by the drawee to the payee discharged not only the drawee towards the payee but also the drawer towards the remitter; similarly, payment by the drawer to the remitter discharged not only the drawer towards the remitter but also the drawee towards the payee.

De Roover's perspective on the legal relationships is thus unlike that of the modern law as outlined above. Nor does De Roover purport to derive explicit support for his position from principles of Roman law. ${ }^{167}$ A most extensive analysis to the contrary, covering a range of views, as to the liability of the drawer and the drawee-acceptor towards the payee and the remitter, is that of Huvelin; the picture he depicts purports both to derive from Roman law and be consistent with modern law. ${ }^{168}$

Regarding the drawer, Huvelin raises a preliminary question as to the very existence of his liability on the bill of payment. Indeed, already in the course of the fourteenth century, it was recognized that having received money from the drawer to be repaid by the drawee to the payee elsewhere, the drawer of the letter of payment was liable to the remitter, the deliverer of money to him, on the basis of the transaction between them. That transaction was either emptio-venditio, ${ }^{169}$ namely purchase and sale, or permutatio, namely barter. ${ }^{170}$ However, this position had not been free from doubt. ${ }^{171}$ In the absence of a signature expressed to be 'with recourse', the document did not contain any undertaking by the drawer; it was merely an instruction by the drawer directed to the drawee to pay to the payee. From this perspective, even the specific drawer's acknowledgement of issuing the instrument against 'value received' was not explicit enough to charge him with an obligation to pay. For these reasons, liability could not be fastened on the drawer on the basis of the Roman law constitutum, which required an undertaking directed to a creditor to pay a pre-existing debt owed to him. Conversely, the bill of payment was a letter addressed to the draweepaymaster, rather than to the payee-creditor, which did not contain any undertaking. By the same token, in the absence of an explicit engagement to that effect, the drawer could not be taken to agree to become a guarantor.

\footnotetext{
163 See J. Marius, Advice Concerning Bills of Exchange (1684), at 17.

164 De Roover, above $n$ 35, at 92-4. $\quad 165$ See text following $n 107$ above.

166 Rogers, above n 111, at 98 . See also Usher, above n 3 , at 88.

167 But $\mathrm{cf}$, text accompanying $\mathrm{nn} 206-7$ below for the reconstruction of De Roover's position according to principles derived from Roman law.

168 Huvelin, above $\mathrm{n} 28$, at 4, 9-21.

169 See, e.g., De Roover, above n 35, at 207, summarizing the position of Baldo Degli Ubaldi (1327-1400).

170 See above $n 83$ and accompanying text.

${ }^{171}$ For a brief discussion on the fourteenth-century debate on this point, see, e.g., Usher, above $n$ 77, at 575 .
} 
According to Huvelin, the drawer was to be made liable on the basis of the delivery of the letter by him to the remitter for further transmission to the payee. That is, while the letter was addressed by the drawer to the drawee, it was not sent by the drawer to the drawee; rather, it was given to the remitter, who was to send it to the payee for presentment to the drawee. According to Huvelin, this circuitous route to the final destination was not devoid of meaning; rather it showed a voluntary undertaking, an assumption of liability, by the drawer as sender towards the party to whom he sent the instrument.

However, it seems to me that Huvelin is not entirely clear as to whose benefit the drawer's liability inures on that basis. Thus, as long as the bill of payment was in the remitter's hands, the drawer's liability ran to the remitter. Conversely, once the bill of payment was in the payee's hands, liability might run in the payee's favour. The theory of drawer's liability towards each one might differ, and Huvelin is not sufficiently clear in explaining as to whom liability ran and on what theory. More specifically, having analysed the issue from the perspective of the drawer-remitter relationship, ${ }^{172}$ he appears, in my view abruptly, to jump to the conclusion that the drawer was nevertheless liable both to the remitter, on the basis of constitutum, as adjusted by mercantile usage, and to the payee, as the destination party who was ultimately to receive the letter of payment, and present it to the drawee, to whom it was addressed. ${ }^{173}$ Against this background, it is hard to tell whether the drawer's undertaking to the payee was autonomous and free from defences available to the drawer against the remitter. Also, the relationship between liability to the remitter and payee was not clear; did the drawer's liability to the payee replace or was it added to the drawer's liability to the remitter? Possibly, Huvelin may be taken to address a transformation in the identification of the party entitled to enforce the drawer's obligation, ${ }^{174}$ and yet he was far from clear in setting out the process.

Alternatively, it is possible to understand Huvelin as saying that on the basis of the route of the letter, the drawer's liability thereunder was not towards the payee, but rather, towards the 'taker ${ }^{\prime 175}$ of the letter from him, namely, the remitter. In such a case, Huvelin's theory as to the original liability of the drawer to the payee, namely prior to acceptance by the drawee, must be taken to be premised on cessio. The transfer was by the remitter to the payee of the remitter's right against the drawer; it was carried out by the delivery of the bill of payment to the payee. This would mean that the payee took the bill of payment subject to all defences the drawer had against the remitter. ${ }^{176}$

The drawer was thus liable in connection with the issuance of the bill of payment; at the same time, the presentment of the instrument by the payee to the drawee precipitated the latter's liability. Originally, the drawee was held liable upon the presentment of the instrument without signing it unless he had disclaimed liability. Subsequently, the drawee's liability became associated with a positive act on his part in response to the presentment, namely the placing of a signature on the instrument, signifying an acceptance by him of the drawer's order to pay.

Two issues arise. The first is the theory underlying the drawee-acceptor's liability. The second is the impact of the drawee-acceptor's liability on that of the drawer.

\footnotetext{
172 Huvelin, above n 28 , at 9-10.

173 Ibid., at 10-11. This is how Huvelin is understood by Foldsworth, above $\mathrm{n} 11$, at 137 and 139.

174 As claimed by Usher, above $\mathrm{n}$ 3, at 89. This transformation is discussed in Section V.

175 'Preneur' in French is both payee and taker. This, however, is not a mere semantic. For the transition from 'taker' of money, viz. the drawer, to 'taker' of the instrument, hence, the payee, as part of the transformation of the bill of payment to a negotiable bill of exchange, discussed in Section V, see De Roover, above n 35, at 117.

176 For cessio, see Geva, above n 1, ch 5, section 9.
} 
Two alternative approaches exist with regard to the first issue, that of the draweeacceptor's liability. Each is derived from Roman law. Thus, the view that ultimately. prevailed in Germany is that the basis of this liability is that of a literal contract, namely, a contract created on the basis of a special kind of writing. It is a formal contract, by definition stricti juris, that is, binding the promissor to the very thing he has promised, and hence unilateral; it may be referred to as abstract. ${ }^{177}$ My own impression is that this contract could be either a variant of, or inspired by, the stipulatio.

At the same time, the alternative, and according to Huvelin the earlier, view that prevailed in France is premised on the theory of la provision, or 'the provision'. ${ }^{178}$ As understood in French law in the late seventeenth century, ${ }^{179}$ la provision was constituted by the sum of money held by the drawee for the drawer, or perhaps, more specifically, provided to the drawee by the drawer, with which the drawee was obligated to pay the bill. However, over the years, la provision acquired a subtler, and in fact broader, meaning, having become the drawer's right towards the drawee, that might not necessarily be constituted only by a sum of money held by the latter for the former. La provision was thus distinguished from 'cover' or 'value'; 'cover' required an actual asset, possibly a sum of money, and 'value' refers to what was, or ought to be, provided by the payee in return for the bill. On the other hand, la provision might be formed by an overdraft that the drawee agreed to provide to the drawer. However, it appeared that in its original meaning under French law, la provision was understood to give rise to either a debt or, effectively, a deposit, ${ }^{180}$ though the latter term may not have been explicitly mentioned. The drawee's obligation arising from holding 'the provision' originally inured for the benefit of the drawer; entitlement passed to the payee when he took the bill. ${ }^{181}$ Its passage to the payee (and subsequently, to each ensuing endorsee) was either a matter of cessio or of 'sale of money'. To that end, the drawee's acceptance was viewed not as a new obligation, but rather, in the footsteps of the constitutum, as an acknowledgement, or confirmation, of an existing one, based on the receipt of 'the provision'. ${ }^{182}$

Under the cessio theory, the drawer transferred to the payee the debt owed to the drawer by the drawee. The drawee's acceptance served the limited function of confirmation; as a matter of legal theory, it was not required to bind the drawee towards the payee. ${ }^{183}$ At the same time, the 'sale of money' theory was premised, first, on viewing the manual money

\footnotetext{
177 For all these types of contract, in the context of the classification of contracts under Roman law, see ibid., ch 5 , section 1 , at $191-4$.

${ }_{178}$ See also Sayous, 'Méthodes commerciales XV', above n 3, at 281.

179 For the statutory reference in 1673, see, e.g., J. V. Tardon, La provision de la lettre de change (droit comparé-loi uniforme) (1939), at 6.

${ }^{180} \mathrm{Cf}$. the distinction in Jewish law between money owed on a loan and on deposit, discussed in Geva, above $\mathrm{n} 1$, ch 7 , section 2, at 309-30. For an earlier meaning, used by Italian and German authors, denoting a commission charged in connection with the issue of a bill of exchange, see, e.g., R. Voegell, La provision de la lettre de change et son attribution au porteur-Étude d'histoire du droit et de droit comparé (Systemes français, allemand et suisse) (1947), at 7-12.

${ }_{181}$ See Gavalda and Stoufflet, above n 133; Ellinger, above n 133; Ripert and Roblot, above n 133. For the meanings of 'la provision', 'value', and 'cover', see Lescot and Roblot, above n 133, at 390, 411-12. For the transfer of la provision as a 'sale' which defeats the drawer's creditors, see, e.g., H. Lévy-Bruhl, Histoire de la lettre de change au France aux XVIIe et XVIIIe siècles (1933), at 91-5. In any event, drawer's creditors are to be defeated also under the cessio theory.

182 For explaining the acceptor's liability as a confirmation of liability, and the procedural advantage accorded to the plaintiff suing on the acceptance in the Low Countries, see W. D. H. Asser, "Bills of Exchange and Agency in the 18th Century Law of Holland and Zeeland-Decisions of the Supreme Court of Holland and Zeeland', in V. Piergiovanni (ed.), The Courts and the Development of Commercial Law (1987) 103, at 112.

${ }_{183}$ See Geva, above n 1, ch 5, section 9, at 233-41.
} 
change transaction as a sale. ${ }^{184}$ Second, it hinged on the analogy between the exchange and the manual change. The former was viewed as if the drawer physically gave coins to the drawee, possibly the same coins delivered to the drawer by the remitter, with a view to charging the drawee with the obligation to give their equivalent to the payee in the currency of payment. In this setting, the drawee's acceptance was the redirection of his agreement to abide by the instruction to the payee's benefit.

Huvelin preferred the 'sale of money' explanation ${ }^{185}$ but acknowledged that ultimately in French law it was the cessio explanation which prevailed. Be that as it may, he pointed at a fundamental distinction between the French and German approaches. Under the German approach, the acceptor's liability as a paymaster was based on his own undertaking to pay off a sum of money, and thus stood on its own; it was for the full amount of the instrument and was not subject to defences that might be available to him as a drawee against the drawer. In short, it is autonomous. Conversely, under the French system, what the acceptor owed to the payee was what, as a drawee, he received from the drawer. In other words, the acceptor was able to meet the payee's action by raising defences available to him as a drawee against the drawer. Stated otherwise, according to Huvelin, under the French system and in contrast to the German one, the acceptor's engagement to the payee was not autonomous; rather, the acceptor's engagement to the payee was that of the drawee-acceptor towards the drawer.

Finally, there is the second issue arising in connection with the presentment to the drawee and the ensuing drawee's liability. This is the question of the payee's recourse against the drawer, either side by side with the payee's entitlement against the draweeacceptor, or upon the default by the drawee-acceptor in dishonouring the instrument. In this scenario, the starting point is the fact that the drawer and payee were not in privity on the bill. It is against this background that De Roover adamantly stated that in case of nonpayment, the sources are unambiguous in their denial to the payee of any recourse against the drawer, who under Medieval law was liable solely to the remitter. ${ }^{186}$

Conversely, Huvelin appeared to assume the existence of the payee's recourse against the drawer, though he may have glossed over its underlying theory; ${ }^{187}$ as indicated, he may have explained the payee's right against the drawer as based either on cessio, or on the routing of the letter from the drawer, not directly to its addressee, the drawee, but rather, indirectly, to the payee via the remitter. ${ }^{188}$ Regardless, Huvelin explained that neither the drawer's order nor the drawee's agreement to abide by it contained any release of the drawer's obligation to the payee. To that end, Huvelin unequivocally rejected the explanation of the drawee's acceptance as the execution of a delegation order in the form of novation by stipulation, as in his view this would have meant the release of the drawer.

Huvelin does not discuss the drawer's recourse against the drawee. Nor does he discuss the drawee-acceptor's liability to the remitter as well as the relationship between the remitter and payee. Presumably, being in privity, relationships between the drawer and the drawee, as well as between the remitter and payee, were governed by respective underlying contracts. In other words, the drawee was likely to be liable to the drawer,

\footnotetext{
${ }^{184}$ For this perspective, see text accompanying nn 118-19 above. At the same time, and notwithstanding Huvelin, above $\mathrm{n} 28$, at $15-16$, I do not see why a different result is produced if the 'sale of money' theory is replaced by barter.

${ }^{185}$ See, in particular, ibid., at 29, where he sees 'the provision' as an extension of the commenda (see discussion in $n 161$ above), on which he rationalizes the drawer-drawee relationship.

${ }^{186}$ De Roover, above n 35, at 92-3. $\quad{ }^{187}$ Huvelin, above n 28, at 19-20.

188 For his discussion as to whom the drawer is liable, see text accompanying nn 172-6 above.
} 
from whom the payee or remitter recovered, on the basis of the commenda or 'provision'. ${ }^{189}$ By the same token, the unpaid payee might recover from the remitter if the latter owed the former and the bill of payment was not given in absolute discharge. ${ }^{190}$ In turn, the drawee might be liable to the remitter, who had not issued the bill, on the basis of the transfer of 'the provision', but not on the basis of the acceptance, which was the drawee's engagement towards the payee. ${ }^{191}$

The preceding discussion demonstrates that adaptation of principles derived from Roman law played a role in the search for an underlying theoretical basis for the bill of payment. Views set out by Huvelin differ as to both the identification as well as the extent of adaptation of relevant principles. Moreover, between De Roover and views canvassed by Huvelin, there appears to be a disagreement regarding fundamental legal features of the instrument, particularly as to the payee's recourse against the drawer, and more generally, the relative position of the parties in privity.

Each approach is in line with its proponent's view as to the prevalent use of the Medieval bill of payment. 'Thus, according to De Roover, the two primary parties to the bill of exchange transaction as relating to a genuine loan agreement were the remitter as lender and the drawer as borrower. In this context, the payee and the drawee were typically the respective agents of the remitter and the drawer. Hence, the primary relationship was between the remitter and the drawer. It was the remitter as lender who 'called the shots'; therefore, the drawer-borrower was responsible only to him, and certainly not to the payee, who was a mere agent for the remitter. ${ }^{192}$ Undoubtedly, it was only as the remitter's agent, and not on the basis of any right of his own, that the payee might sue the drawer, as well as the drawer's agent, namely the drawee. ${ }^{193}$ Conversely, Huvelin views the mechanism as primarily designed for the transmission of a non-cash payment from a debtor (remitter) to his creditor (payee); ${ }^{194}$ in this context, it was only logical to provide the payee-creditor with a direct cause of action against the drawee-paymaster, to whom the drawer-debtor delegated his payment obligation to the payee-debtor. It was thus the economic function and not the mechanical application of general principles of Roman law that underlay the disagreement as to fundamental legal features.

Seventeenth-century classic English authors discuss the matter along lines that unequivocally support De Roover's position as to the strict privity requirement. First, writing in 1622, Malynes discussed a somewhat complex bill of exchange transaction involving a chain of remitters. ${ }^{195}$ In this context, Malynes was clear as to strict privity requirements. Thus, upon the dishonour by the drawee, it was the drawer who had to pay. In turn, upon his failure to pay, the drawer incurred liability exclusively to the remitter, who gave him the money. ${ }^{196}$ Interestingly, in the context of this scenario, Malynes did not discuss-and in fact did not even mention-liability of, or even acceptance by, the drawee. However, elsewhere, Malynes mentioned that according to 'the opinion of... Merchants', the payee might recover from the acceptor, notwithstanding the insolvency of the

\footnotetext{
189 See Huvelin, above n 28, at 29, and discussion at nn 161 and 185 above.

190. Whether a bill is taken in conditional or absolute discharge is discussed in text accompanying $\mathbf{n} 137$ above,

191 Cessio was discussed in connection with the payee's entitlement from the drawee as well as from the drawer. See, respectively, text accompanying nn 159 and 179 above.

192 De Roover, above n 35, at $92-4$ and 115-17.

193 For this position of the payee vis-à-vis the drawee in Holland and Zeeland during the eighteenth century, see Asser, above n 182.

${ }_{194}$ The two conflicting views as to the function and hence the operation of the mechanism are set out in text accompanying nn 106-11 above.

195 Malynes, above n 58, at 395-6. 196 Ibid., at 400.
} 
drawer. ${ }^{197}$ This confirms both the privity requirements and the acceptor's liability. At the same time, this absolute entitlement in the hands of the payee, irrespective of the drawer's insolvency, suggests that the drawee was liable other than as drawer's agent. Presumably this liability was based on the binding effect of the acceptance. Alternatively, however, the drawee's liability could be seen as derived from his accountability for proceeds realized from the sale of the drawer's goods for whose procurement the drawer owed the payee's associate, namely, the remitter.

Second, writing in $1651,{ }^{198}$ namely, a quarter of a century later, Marius may even be more explicit. To begin with, he confirmed the binding effect of the acceptance, even when given orally. ${ }^{199}$ Next, he stated that by delivering the money to the drawer, the remitter is rightly and properly Master' of the bill until it falls due. ${ }^{200}$ Thereby, Marius undoubtedly inspired De Roover, who nevertheless cited Malynes in support of that proposition. ${ }^{201}$ However, it does not follow that the acceptor was liable to the remitter; rather, according to Marius, until satisfaction, the drawer was liable to the remitter, while the acceptor's liability inured to the benefit of the payee. Also in the footsteps of Malynes, Marius treated the acceptor's liability as enforceable by the payee irrespective of the drawer's bankruptcy. ${ }^{202}$

Presumably, satisfaction is either by the drawer's payment to the remitter or the drawee's payment to the payee, so that effectively, payment by one releases the other. Only where the payee was an agent of the remitter, a typical situation according to De Roover, ${ }^{203}$ were both the drawer and the drawee/acceptor liable to the remitter; ${ }^{204}$ and yet Marius did not even mention the possibility of the drawer becoming liable to the payee. ${ }^{205}$

This is certainly different from the position under modern law as well as from the picture described by Huvelin. Nevertheless, it does not follow that a doctrinal common denominator is not available. Thus, the fundamental practical difference between Huvelin and De Roover is on the issue of the drawer's liability to the payee. It is on the basis of an analysis of general principles derived from Roman law that Huvelin gave a positive answer. ${ }^{206}$ On his part, De Roover did not cite Roman law principles; however, it does not follow that they were necessarily contrary to his position. The following is an attempt to juxtapose both alternative views in a framework built on an expanded view of legal principles derived from Roman law.

Thus, the remitter delivered money to the drawer and instructed him to repay its equivalent denominated in another currency to a payee located elsewhere. In return, the drawer delivered to the remitter the letter of payment in which the drawer instructed the drawee, located in the place of payment, to pay to the payee. The remitter sent the letter to the payee who presented it to the drawee first for acceptance and on the due date for payment. The scenario thus involved two payment orders, one by the remitter addressed to

\footnotetext{
197 Ibid, at 401. Marius, above 163, 'Preface to the Reader'. Unless otherwise indicated, all references in this chapter to Marius's book are to the 1684 edition.

199 Marius, above 163 at 20 (irrevocability of acceptance) and 16 (verbal acceptance which may be Marius, above n 163, at 20 (irrevocabllty of acceptance) an 10 of the 1651 edition).
constituted by a witnessed promise to accept) (respectively, at 24 and

200 Marius, above $n 163$, at 17 (at 16-17 of the 1651 edition).

201 De Roover, above n 35, at 116-17 references above n 133.

202 Marius, above $n 163$, at 20 (at 24 in the 1651 edition).

${ }^{203}$ See discussion in text accompanying $n 108$ above.

204 Sarius, above $n 163$, at $26-7$ (at 46-8 of the 1651 edition).

205 (effectively a paymaster for a buyer) liable to the payee (a seller) is Chat and Edgar Case (1663), 1 Keble 636, 83 ER 1156, further discussed in Geva, above n 1, ch 9, section 4, at 442-53. 206 See above text accompanying nn 168 et seq.
} 
the drawer, and the other, embodied in the letter of payment, that of the drawer addressed to the drawee. They are to be analysed as follows:

(1) - Where the remitter wished to pay to the payee in the discharge of a debt, the remitter's payment order was viewed by Huvelin as a delegation order. By executing it, the drawer became directly liable to the payee. Depending on the parties' intention and the mechanism chosen, execution might either be perfect or imperfect, with the remitter released in the former and remaining liable in the latter. Moreover, and this is particularly relevant when the payment that the remitter wished to be made was not in the discharge of a debt owed by the remitter to the payee, the drawer might become liable to the payee even other than in the execution of a delegation order, either by forming with the payee a direct contract, or having his debt to the remitter transferred to the payee.

- At the same time, according to De Roover, the drawer's payment order was neither an execution of a delegation order, nor the basis for a direct contract with the payee; nor was there a cessio to the payee of the drawer's debt to the remitter. Rather, it was a simple mandate, pursuant to the drawer's agreement with the remitter, which did not affect the payee's relationship with the drawer nor with the remitter.

(2) The second payment order was that of the drawer to the drawee; this was the one contained in the letter of payment:

- Where it was in connection with the payment of a debt owed by the remitter to the payee, it was to be viewed by Huvelin as an imperfect execution of the drawer's payment order so as to leave the drawer liable to the payee.

- Otherwise, and certainly according to De Roover, it gave rise to a separate independent contract formed by the drawee with the payee. In this framework, the drawer did not incur liability to the payee.

Usher refers to what is effectively Huvelin's discussion as 'establishing the letter of payment as a type of the Roman agreement to discharge a debt'. ${ }^{207}$ To a large extent, the preceding analysis demonstrates that De Roover's position could have equally been founded on the basis of principles derived from Roman law. In fact, the flexibility of such principles is a source of both strength and weakness; the strength is in the resilience of these principles to support the inclusion of both new and changing circumstances; the weakness is that as such, they can easily be manipulated, so that on their own, they lack predictability as to the ultimate result.

\section{Conclusion: Medieval Continental Contribution Assessed}

Having discussed medieval private and public banks, De Roover summarized as follows:

From the sixteenth century until the end of the eighteenth century, the banking system on the European Continent was made up of public banks, which continued the functions inherited from the medieval moneychangers, and of private bankers or cambists who, also in accordance with traditions dating back to the Middle Ages, were mainly exchange dealers. In all the manuals of the seventeenth and eighteenth centuries, a banker is defined as a dealer in bills of exchange who operates with correspondents abroad and speculates on the rates of exchange. ${ }^{208}$

\footnotetext{
207 Usher, above n 3, at $89 . \quad 208$ De Roover, above n 15, at 229.
} 
It is in this institutional framework, as it has evolved since the twelfth century, that medieval non-cash payment facilities have developed. Thus, the bank book transfer and the emergence of cheques are developments that took place in activities of moneychangers turned deposit bankers. At the same time, the bill of exchange, including its predecessor, the bill of payment, evolved as part of the activities of exchange dealers, namely private merchant bankers.

Outside deposit banking, non-cash payment instruments proliferated in the early Middle Ages in the Islamic lands. ${ }^{209}$ Such instruments may have been known in Europe; nevertheless, the bill of exchange appears to be the creation of medieval continental Europe. Building on the flexibility of concepts inherited from Roman law, medieval law facilitated the crystallization of its legal features as a credit and payment mechanism. Ultimately however, the bill of exchange was transformed from a payment and credit facility, into predominantly a credit tool, and yet, it came to confer its features on the cheque. More generally, the post-medieval banking system in England transformed into the true machinery for financial intermediation; this transformation enhanced non-cash payment facilities developed in the Middle Ages and built on them the foundation of the modern payment system. ${ }^{210}$ In the final analysis, while having been subsequently transformed, elements of medieval banking, cheques, and bills of exchange, whether original or not, heralded the modern banking and payment systems.

A distinctive contribution of the medieval era is the settlement procedure for bills of payments conducted by merchant bankers in fairs. This procedure is the forerunner of organized multilateral interbank clearing. Its own operation was premised on a series of co-ordinated bilateral nettings occurring in an organized multilateral setting, allowing the substitution of debtors so as to enhance savings in actual payments. ${ }^{211}$ This was performed in the context of a multilateral organization, and heralded the next transformative step, that of the clearing house with its multilateral netting. Thus, historically, the medieval fair interbank facility was the genesis of the interbank clearinghouse, and led to the performance of interbank multilateral clearing.

\footnotetext{
209 For a detailed discussion, see Geva, above $\mathrm{n} 1, \mathrm{ch} 6$, at 252-306.

210 Both aspects, that is the characterization of a cheque as a specie of a bill of exchange and the post-Medieval transformation of the banking system in England, are outlined in ibid., ch 10, at 467-527.

${ }^{211}$.ndeed, bilateral and even multilateral netting, practised in isolation by banks on ad hoc basis, had been already known in Antiquity. For origins in Ancient Greece, see ibid., ch 3, section 3, at 124-32. At the same time, the Medieval fair interbank facility was premised on all pairs acting in a multilateral setting and taking advantage of this facet by allowing substitution.
} 